\title{
Modulating Th2 Cell Immunity for the Treatment of Asthma
}

\author{
Beatriz León ${ }^{1 *}$ and Andre Ballesteros-Tato ${ }^{2 *}$ \\ ${ }^{1}$ Department of Microbiology, University of Alabama at Birmingham, Birmingham, AL, United States, ${ }^{2}$ Division of Clinical \\ Immunology and Rheumatology, Department of Medicine, University of Alabama at Birmingham, Birmingham, AL, \\ United States
}

OPEN ACCESS

Edited by:

Thomas Malek

University of Miami, United States

Reviewed by:

Muriel Moser,

Université Libre de Bruxelles, Belgium Zhibin Chen,

University of Miami, United States

${ }^{*}$ Correspondence:

Beatriz León

bleon@uab.edu

Andre Ballesteros-Tato

andreballesterostato@uabmc.edu

Specialty section:

This article was submitted to Immunological Tolerance and Regulation,

a section of the journal

Frontiers in Immunology

Received: 04 December 2020

Accepted: 21 January 2021

Published: 10 February 2021

Citation:

León B and Ballesteros-Tato A (2021)

Modulating Th2 Cell Immunity for the

Treatment of Asthma.

Front. Immunol. 12:637948.

doi: 10.3389/fimmu.2021.637948
It is estimated that more than 339 million people worldwide suffer from asthma. The leading cause of asthma development is the breakdown of immune tolerance to inhaled allergens, prompting the immune system's aberrant activation. During the early phase, also known as the sensitization phase, allergen-specific $T$ cells are activated and become central players in orchestrating the subsequent development of allergic asthma following secondary exposure to the same allergens. It is well-established that allergen-specific T helper 2 (Th2) cells play central roles in developing allergic asthma. As such, 80\% of children and $60 \%$ of adult asthma cases are linked to an unwarranted Th2 cell response against respiratory allergens. Thus, targeting essential components of Th2-type inflammation using neutralizing antibodies against key Th2 modulators has recently become an attractive option for asthmatic patients with moderate to severe symptoms. In addition to directly targeting Th2 mediators, allergen immunotherapy, also known as desensitization, is focused on redirecting the allergen-specific $T$ cells response from a Th2-type profile to a tolerogenic one. This review highlights the current understanding of the heterogeneity of the Th2 cell compartment, their contribution to allergen-induced airway inflammation, and the therapies targeting the Th2 cell pathway in asthma. Further, we discuss available new leads for successful targeting pulmonary Th2 cell responses for future therapeutics.

\section{Keywords: Th2 airway inflammation, Tfh cell, asthma, cytokines, T cell}

\section{INTRODUCTION}

Asthma is a chronic lung disease characterized by breathing problems and obstructed airflow when airways swell and narrow and produce excess mucus (1). Allergic asthma is the most common form of asthma and is caused by the inhalation of allergens, which trigger the overreaction of the immune system in allergic people (1). The most common airborne allergens are pollen, fungal spores, house dust mites (HDM), and animal allergens. The characteristic pattern of inflammation in the airways of patients with allergic asthma includes the production of $\mathrm{T}$ helper 2 (Th2)-associated cytokines, such as interleukin- (IL-) 4, IL-13, and IL- 5 by Th2 cells and type 2 innate lymphoid cells (ILC2s), the activation of mast cells, the infiltration and activation of eosinophils, and the increased production of immunoglobulin E (IgE) by B cells (2). Clinical and preclinical studies demonstrate a strong cause and effect relationship between the aberrant expansion of allergen-specific Th2 $\mathrm{CD} 4^{+}$ $\mathrm{T}$ cells and the development of asthma pathogenesis, thus leading to the idea that Th2 cells play a central role in allergic asthma $(1,2)$. 
The development of allergic asthma occurs in two phases $(1,3)$. Phase one requires an initial exposure to allergen or "sensitization" that does not necessarily cause symptoms or pathology. Phase two is characterized by pathology development following secondary or subsequent allergen exposures or "challenges." Initial sensitization to airborne allergens occurs typically in early childhood, and it is characterized by the initial priming of allergen-specific $\mathrm{CD} 4{ }^{+} \mathrm{T}$ cells with a Th2-like cytokine profile. These $\mathrm{T}$ cells persist after the initial priming and can be subsequently reactivated upon re-exposure with the same inhaled allergen, which caused their migration to the airways, where they locally produce Th2 cytokines. The accumulation of effector Th2 cells in the lungs ultimately stimulates the hallmark features of asthma, such as mucus hypersecretion and bronchial hyperresponsiveness (1).

Most patients with asthma achieve good disease control with the principal use of inhaled corticosteroids and bronchodilators $(4,5)$. However, a large proportion of patients with asthma remain poorly controlled (6). The failure of conventional therapies in these corticosteroid-resistant patients justifies looking for new approaches to treat allergic asthma. In this regard, the central role of Th2 cells in regulating airway inflammation has aroused great interest in the therapeutic potential of "anti-Th2 approaches." As such, new biological asthma medications based on monoclonal antibodies against key Th2 mediators have been recently approved, and more are being under investigation (7). Furthermore, allergen immunotherapy, a long-term treatment that inhibits Th2-cell-mediated responses, decreases symptoms for many people with allergy disease (8), thereby evidencing the central pathogenic role of Th2 cells in the pathophysiology of allergy.

Here, we will review the available treatments for allergic asthma and discuss the potential immunological mechanisms underlying the clinical benefits of these therapies. Finally, recent studies provide evidence of a critical function of $\mathrm{T}$ follicular helper (Tfh) cells, a subset of $\mathrm{CD}^{+} \mathrm{T}$ cells that help GC B cell responses, in the allergic asthma pathogenesis. Therefore, we will discuss potential therapeutic approaches to target Tfh cells and suppress IgE responses and Th2 cell-mediated allergic inflammation in asthmatic patients.

\section{PATHOGENIC ROLES OF Th2 CYTOKINES IN ALLERGIC ASTHMA}

Eighty percentage of children and $60 \%$ of adults with asthma have type $2 /$ Th2 asthma (9), which is driven by allergen-induced production of IgE and Th2 cytokines, including IL-5, IL-13, and IL-4 (Figure 1). Studies in mice, initially using OVA adjuvant and adjuvant-free sensitization protocols and most recently, using natural allergens such as HDM, cockroaches, sensitizing fungi, and protease allergens, have demarcated our knowledge on Th2 cytokines in asthma. For example, IL- 4 produced by $\mathrm{T}$ cells drives IgE class switching (10-15) and, in conjunction with IL13 , is required to produce high-affinity $\operatorname{IgE}(16)$. IgE mediates mast cell and basophil degranulation by FceRI crosslinking upon allergen recognition (17-19). Activation of FceRI results in the immediate release of preformed granular substances (e.g., histamine, heparin, and proteases) and the production of inflammatory mediators, such as cytokines and arachidonic acid metabolites. This activation drives edema, mucus hypersecretion, and bronchial hyperresponsiveness, all accompanied by a drop in airflow in the airways. In some cases, activation of Fc\&RI can develop into a life-threatening systemic reaction called anaphylaxis (20).

In addition to regulating IgE production, IL-13 and IL4 are implicated in cardinal features of asthma, such as extravasation and trafficking of eosinophils into the tissue (2127), goblet cell maturation, mucus secretion (28), bronchial hyperresponsiveness $(28,29)$, and tissue remodeling (30).

IL-5 is responsible for the maturation of eosinophils in the bone marrow and their release into the blood (31). As such, IL-5 production in the airways favors the production, accumulation, and activation of eosinophils in the lung (32), and ultimately, the release of a large number of mediators capable of inducing bronchial hyperresponsiveness, mucus hypersecretion via enhanced differentiation of goblet cells (33-36) and, airway remodeling $(37,38)$.

Although ILC2s and other cells can also contribute to Th2 cytokines production, IL-4, IL-13, and IL-5 are principally produced by Th2 cells during ongoing chronic asthmatic responses. Given the pathogenic role of Th2 cells and Th2 cytokines, treatments for patients with type $2 / \mathrm{Th} 2$ asthma are directed to globally suppress Th2-mediated inflammation or to specifically target the most pathogenic effector functions of the various Th2 cytokines or the IgE response.

\section{CONVENTIONAL TREATMENTS THAT TARGET Th2-TYPE INFLAMMATION IN ASTHMA}

Inhaled corticosteroids (ICS) are the most effective and commonly used long-term control drugs for asthma $(4,5)$. They locally suppress many aspects of Th2 cell-mediated inflammation, including Th2 cytokines (IL-4, IL-13, IL-5) epithelium-derived cytokines (TSLP, IL-33), chemotactic chemokines (IL-8, RANTES, MIP-1 $\alpha$, eotaxin, CCR2), and adhesion molecules (ICAM-1, VCAM-1) (4, 5, 39-41). Globally, ICS reduce the recruitment and maintenance of inflammatory cells into the airways of asthmatic patients, including dendritic cells, Th2 cells, eosinophils, and mast cells. Mechanistically, ICS suppress the production of chemotactic mediators, prevent the expression of adhesion molecules, and inhibit the survival of inflammatory cells in the airways $(4,5)$.

ICS mediate their effects through the glucocorticoid receptor (GR), an intracellular receptor and transcription factor belonging to the nuclear receptor family (39). In the absence of the ligands, GR is maintained in the cytoplasm by chaperone proteins. Upon ligand binding, GR becomes active and translocates into the nucleus to bind glucocorticoid response elements (GREs), thereby regulating the transcription of GR target genes. GR dimers and monomers can induce either transcriptional gene induction or gene repression $(39,42-44)$. Besides, GR 


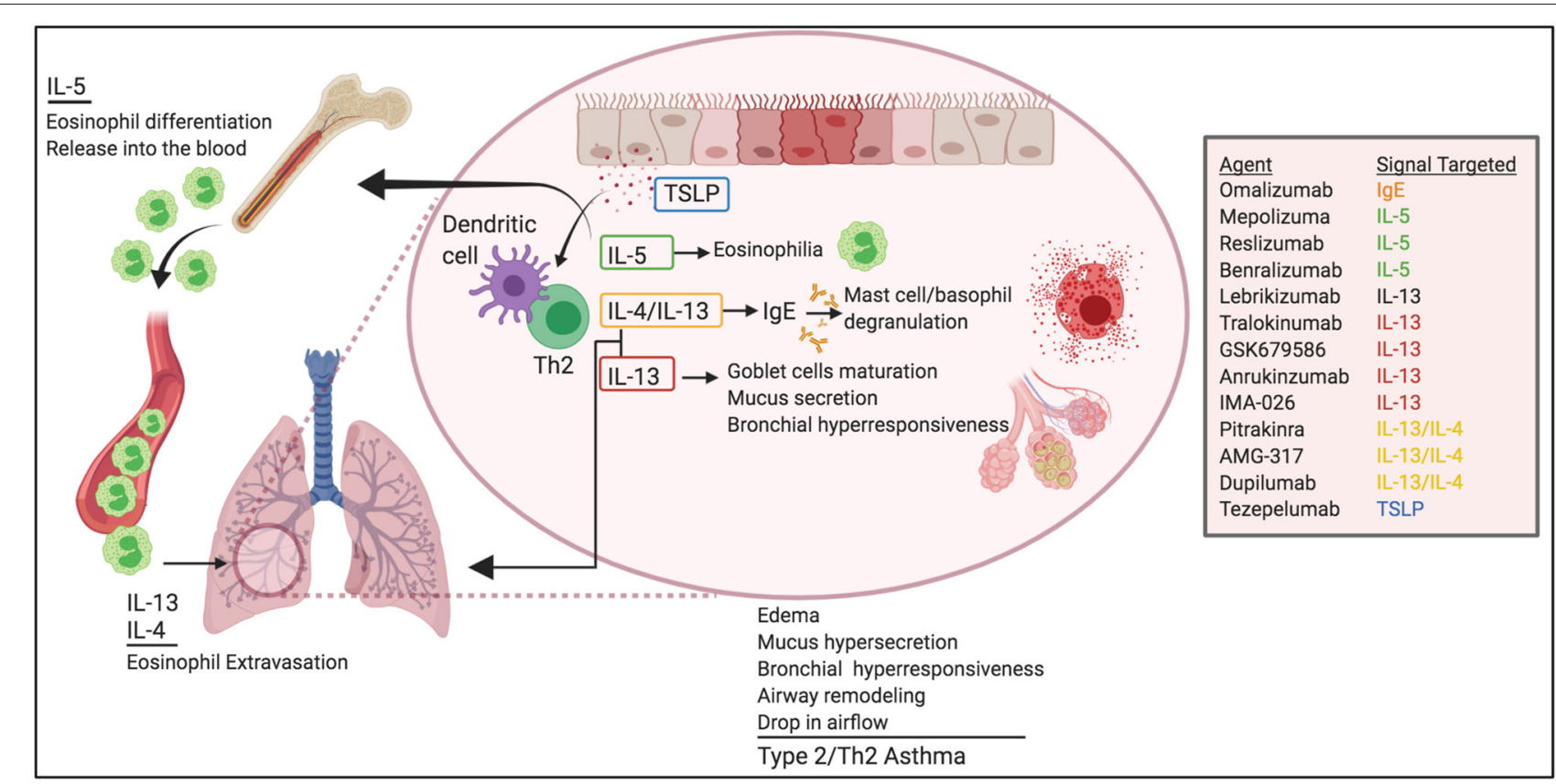

FIGURE 1 | Pathogenic roles of Th2 cytokines in allergic asthma. Th2 cytokines play critical roles in asthma pathogenesis. IL-5 promotes eosinophil egress from the $\mathrm{BM}$ and help survival in the lungs. IL-4 and IL-13 induce eosinophil extravasation from the blood into the tissue and promote IgE class-switching. IL-13 favors globet cell maturation, mucus secretion, and airway hyperresponsiveness. TSLP helps Th2 differentiation and DC function. Altogether, these effects lead to edema, mucus hypersecretion, bronchial hyperresponsiveness and remodeling, and ultimately drop in air-flow and asthma. Novel biological therapeutics target these pathways for the treatment of asthma.

can indirectly induce gene repression by GR interaction with DNA-bound transcription factors such as NF- $\mathrm{B}$ and activator protein-1 (AP-1), resulting in the repression of the respective inflammatory signaling cascades $(39,45,46)$.

The wide range of anti-inflammatory effects of ICS probably accounts for their clinical effectiveness in managing type 2/Th2asthma. Regular treatment with ICS (alone or in combination with bronchodilators, such as long-acting $\beta 2$ agonists (LABAs) or Theophylline) can effectively control chronic symptoms and prevent asthma attacks in most of the patients $(4,5)$. However, in patients with moderate to severe asthma, ICS are less effective. Hence, unacceptably high doses of ICS or even oral corticosteroids may be required to achieve optimal control.

Several mechanisms can contribute to the reduced responsiveness to ICS in moderate/severe asthma [for a review, see (6)]. For example, cytokines such as IL-1, TNF $\alpha$, nitric oxide (NO), IL-13, and IL-4, which are overexpressed in the airways of patients with corticosteroid-resistant asthma, have been shown to reduce GR nuclear translocation and function. Ultimately, people with severe asthma are refractory to ICS treatment and experience poor symptom control. Additionally, these patients can have frequent asthma exacerbations, in which symptoms flare-up and get progressively worse, leading to respiratory failure. Therefore, new treatments have emerged for selected patients with moderate to severe type 2/Th2 asthma disease and inadequate responsiveness to ICS. These new therapeutic avenues are aimed to target cytokines and mediators that promote type $2 /$ Th2 immunity.

\section{Biologic Drugs That Target Th2-Type Inflammation in Asthma}

The clinical characteristics of moderate/severe asthma disease are frequent asthma exacerbations ( $>2$ episodes in 12 months period), high blood counts of eosinophils and sputum eosinophils, and poor response to high dosage ICS/ LABAs (47). These uncontrolled symptoms place patients at high risk for hospitalization and reduced health-related quality of life. Therefore, additional therapeutics are needed for those patients whose severe asthma does not respond well to conventional anti-inflammatory treatment. Several biologics designed to target specific mediators of Th2-type cell immunity have been proved to be effective as add-on treatments for severe asthma patients (Figure 1).

\section{Anti-IgE Therapy in Severe Asthma: Omalizumab}

Omalizumab is a humanized IgG1 monoclonal antibody that specifically binds to free $\operatorname{IgE}$ and prevents it from binding to the high-affinity IgE receptor (FceRI) on basophils and mast cells. As Omalizumab depletes free IgE, it further promotes FceRI downregulation in basophils and mast cells, rendering those cells much less sensitive to stimulation by allergens and consequent degranulation (48-50).

Omalizumab is given by subcutaneous injection every 2-4 weeks. It is FDA-approved to treat moderate-to-severe asthma in patients over 6 years of age that have sensitivity to perennial aeroallergens (e.g., dust mites, pet dander, cockroach debris). The appropriate doses are determined on a combination of age, 
IgE levels, and body weight. In clinical trials and observational studies with moderate to severe persistent asthma patients, Omalizumab has been shown to decrease the incidence of asthma exacerbations and emergency visits by 38 and $47 \%$, respectively, compared with controls (50).

Some potential adverse reactions have been described related to long-term effects on cardiovascular and cerebrovascular events. However, the available studies limit the ability to quantify the magnitude of the risk $(50,51)$. Omalizumab has also been associated with life-threatening systemic allergic anaphylactic reactions; thus, anyone who gets an injection of this drug should be monitored closely by health professionals (50).

\section{Anti-IL-5 Therapy in Severe Asthma: Mepolizumab, Reslizumab, and Benralizumab}

Three different biologic drugs targeting IL-5 signaling are available, and FDA-approved. All three treatments have been consistently shown to reduce blood eosinophil counts and sputum eosinophils $(47,52,53)$. Mepolizumab is a humanized IgG1 monoclonal antibody that recognizes and blocks IL-5 and prevents its binding to IL-5 receptor alpha subunit (IL$5 \mathrm{R} \alpha$ or CD125) on the surface of eosinophils. Reslizumab is a humanized IgG4 monoclonal antibody against IL-5 that likewise prevents IL-5 function in eosinophils. Finally, Benralizumab also targets IL-5-mediated effects on eosinophils, but in this case, it is via a humanized IgG1 monoclonal antibody directed against IL-5R $\alpha / C D 125$. Besides, blocking IL-5/IL-5R signaling, Benralizumab induces antibody-mediated eosinophil depletion (54) and as such, very rapid eosinophil reduction in sputum, bone marrow and blood (53).

Targeting the biological activity of IL- 5 with Mepolizumab, Reslizumab and Benralizumab reduces asthma exacerbations and life-threatening emergencies in corticosteroid-resistant severe eosinophilic asthma, as well as help minimize corticosteroid use (55-69). However, no consistent benefits have been shown to improve daily asthma symptoms and quality-of-life, pertaining to the use of short-acting bronchodilators, nigh awakenings, or the limitation of activities (55-57, 62, 66, 67, 70). Likewise, targeting IL-5 does not improve asthma control in patients with mild-tomoderate eosinophilia $(59,71-73)$. Hence, while these findings highlight the importance of eosinophils in the pathogenesis of asthma exacerbations, they also suggest that the inflammatory cues driving the day-to-day symptoms are different from the eosinophil-driven mechanisms responsible for asthma attacks. Therefore, the primary target population for these medications is limited, at best, to patients with moderate-to-severe eosinophilia and a history of frequent exacerbations.

The three current FDA-approved anti-IL-5 therapies have different administration routes and schedules. Mepolizumab is given as an at-home monthly subcutaneous injection and approved as an add-on treatment for patients 6 and older. Reslizumab is a personalized, weight-based intravenous injection given every 4 weeks and approved for use with other asthma medicines in patients aged 18 and older. Due to the risk of an anaphylactic reaction, patients should be observed after drug administration. Benralizumab is an add-on maintenance treatment for patients 12 and older and is administered once every 4-8 weeks by subcutaneous injection. A healthcare professional should oversee Benralizumab administration due to the risk of anaphylaxis.

\section{Anti-IL-13/4 Therapy in Severe Asthma}

Due to the central role of IL-13 and IL-4 in controlling critical aspects of asthma pathophysiology, several biologic drugs have been designed to block either IL-13 alone or IL-13 and IL-4 simultaneously. IL-13 signals primarily through the Type-2 IL-4 receptor, which is composed of two chains, IL-13R $\alpha$ and IL-4R $\alpha$ IL-4 can signal through both, the Type-2 IL-4 receptor and the Type 1 IL-4 receptor (consisting of IL- $4 \mathrm{R} \alpha$ and common $\gamma$ chain).

IL-13 alone blocking drugs include monoclonal antibodies against IL-13 such as Lebrikizumab (humanized IgG4), Tralokinumab (human IgG4), GSK679586 (humanized IgG1), Anrukinzumab (IMA-638; humanized IgG1) and IMA-026 (humanized IgG1). Simultaneous targeting of IL-4 and IL-13 signaling has been achieved by using a human IL-4 mutein that competes with IL-13 and IL-4 for binding to the IL- $4 \mathrm{R} \alpha$ (Pitrakinra), and by using monoclonal antibodies against IL-4R $\alpha$ (AMG-317, human IgG2 and Dupilumab, human IgG4).

IL-13 blocking agents show evidence of IL-13 pathway inhibition, such as a reduction in biomarkers of Th2/eosinophilic airway inflammation and serum IgE concentration. However, they do not consistently show clinically meaningful improvements in asthma control, pulmonary function, or exacerbations in severe asthma patients (74-83), most likely due to the inability of IL-13 blocking agents to reduce airway eosinophilia in humans significantly $(79,83)$. Collectively, these results do not support the use of Lebrikizumab, Tralokinumab, GSK679586, Anrukinzumab, and IMA-026 for the treatment of severe asthma.

The biologic activities of IL-14 and IL-13 significantly overlap. Thus, the relatively low efficacy of IL-13 blocking agents is likely due to the capacity of IL- 4 and other inflammatory mediators to compensate for the lack of IL-13. Therefore, dual targeting of IL13 and IL-4 has been suggested as a superior approach to reduce airway eosinophilia and other activities associated with airway inflammation, fibrosis, and mucus production (84). In agreement with this idea, local (inhaled) treatment with Pitrakinra, an IL4 mutein that simultaneously blocks IL-13 and IL-4 signaling, has shown clinical efficacy in reducing asthma symptoms in a phase 2 a study in patients with mild asthma (85). In a later larger study, inhaled Pitrakinra showed significant clinical efficacy in reducing the rate of exacerbations in patients with moderate-tosevere eosinophilic asthma (86). Despite these promising data, further development of Pitrakinra for asthma has ceased.

Additionally, two monoclonal antibodies to IL-4R $\alpha$ have been developed for the dual inhibition of IL-4/13 signaling (AMG-317 and Dupilumab). AMG-317 displayed relatively poor pharmacokinetics and did not demonstrate clinical efficacy in a clinical trial with moderate-to-severe asthma patients (87). Dupilumab, however, has shown clinical improvements in reducing asthma exacerbations and asthma symptoms and control, as well as lung function in patients with persistent, moderate-to-severe asthma and elevated eosinophil levels (8891). Besides, Dupilumab appears to have a more significant 
effect in improving bronchial hyperreactivity than inhibitors of IL-5 and significantly reduce levels of Th2-associated inflammatory indicators, including markers of eosinophilic airway inflammation and $\operatorname{IgE}$ levels $(88,89)$. IL-4 and IL13 are essential factors promoting Th2 cell differentiation and class switching into IgE in B cells (1), but at the same time, precluding the differentiation of regulatory T cells (Tregs) (9295). Therefore, the blockade of the actions of IL-4 and IL-13 with Dupilumab could potentially alter the course of adaptive immune responses to allergens and thus cause a long-term tolerogenic effect. If this is confirmed, Dupilumab could be considered not only a Th2-targeted therapy but an immunomodulatory therapy as well.

Up until now, Dupilumab is the only FDA-approved dual inhibitor of IL-4 and IL-13. It is currently used as an add-on maintenance treatment in patients with moderate-tosevere asthma aged 12 years and older with an eosinophilic phenotype or oral corticosteroid-dependent asthma. It is also approved for inadequately controlled chronic rhinosinusitis with nasal polyposis and atopic dermatitis (96-98). The drug is administered once every 2 weeks by subcutaneous injection and is administered at home or in office.

Interestingly, though Dupilumab decreases bronchial hyperreactivity, serum IgE, and pulmonary eosinophilia, eosinophil counts in blood are elevated $(88,89)$. This observation is not entirely surprising since, rather than inhibiting eosinophil differentiation, the likely mechanism by which IL-4/IL13 blockade prevents airway eosinophilia is by precluding eosinophils recruitment from the blood into the tissues (21-27). Notably, IL-5 stimulates eosinophil development, maturation, and egress from bone marrow (31). As a result, anti-IL-5-based therapies significantly reduce eosinophil numbers in both blood and sputum $(47,52,53)$. Therefore, combined blockade of multiple Th2-associated cytokines (IL-13, IL-4, and IL-5) may be a better approach to overcome cytokine redundancy and gain full control of asthma symptoms, including exacerbations, lung function, and quality of life, by simultaneous optimization of airway hyper-reactivity, eosinophil, and IgE targeting (99).

\section{Promising New Therapy in Severe Asthma Targeting the Epithelial-Cytokine TSLP: Tezepelumab}

The epithelial cell-derived cytokine thymic stromal lymphopoietin (TSLP) has been described as a central regulator of Th2 cell-mediated inflammation in asthma (100-104). Several studies have shown that the airways of asthmatic patients have increased TSLP expression, which correlates with higher Th2 cell response and disease severity (100-103, 105). In vitro approaches and in vivo animal models have demonstrated that TSLP is released by the barrier epithelium in response to external insults, particularly to allergens with proteolytic activity, such as HDM, cockroaches, ragweed, Alternaria, Aspergillus, and papain (106-113). Additional preclinical studies demonstrate that the lack of TSLP signaling results in reduced Th2 cellmediated airway inflammation $(106,114,115)$. On the contrary, TSLP overexpression leads to spontaneous Th2 cell-mediated airway inflammation and an asthma phenotype $(115,116)$. Mechanistically, TSLP can directly stimulate naïve $\mathrm{CD} 4^{+} \mathrm{T}$ cells to commit to the Th2 cell lineage $(106,114,117)$ and directly stimulate dendritic cells $(103,106,113,115,118,119)$ and ILC2 (106, 113, 120-122) for priming Th2 cell responses.

Based on the central role of TSLP in the initiation and maintenance of Th2-cell-mediated inflammation, including not only asthma but also atopic dermatitis and food allergy (123), a human IgG2 monoclonal antibody with the ability to neutralize TSLP (Tezepelumab) was developed (124) and have shown promising results in severe, uncontrolled asthma (125-127). Tezepelumab was given as an add-on therapy to patients whose asthma was uncontrolled despite the use of ICS. It was found to reduce asthma exacerbations, allergeninduced bronchoconstriction, and airway inflammation indexes, including decreased levels of blood and sputum eosinophils. These findings are being further explored in an ongoing phase $2 / 3$ trial that will produce data by early 2021 . Current trials are testing Tezepelumab when given subcutaneously every 4 weeks. Additionally, an inhaled anti-TSLP antibody will be studied in a 652-patient Phase II study (NCT04410523) that has yet to start recruiting.

\section{ALLERGEN IMMUNOTHERAPY OR ALLERGEN DESENSITIZATION}

Allergen immunotherapy, also known as desensitization, is a long-term medical treatment that decreases symptoms and prevents the development of allergic asthma in patients with environmental allergies (128-131). Contrary to ICS, oral corticoids, LABAs, and biologic drugs, which require continuous utilization to keep asthma symptoms under control, allergen immunotherapy is a disease-modifying approach. In these therapies, patients are exposed to gradually increasing doses of environmental allergies to divert their pathogenic Th2 cell responses from pathogenic to tolerogenic. The treatment requires a significant commitment since it usually takes 3-5 years to achieve clinical benefits. However, it often leads to long-lasting relief of allergy symptoms and severity of asthma, with an observed efficacy duration of 7-12 years after treatment is stopped (129-135). Allergen Immunotherapy may also decrease the development of new sensitizations to other allergens in both pediatric and adult patients $(8,131)$.

Despite proven efficacy, the mechanisms of allergen immunotherapy remain not entirely understood. Multiple overlapping mechanisms, mediators, and cell types are likely responsible for re-directing the established Th2/IgE-dominant response and the restoration of the immune tolerance to the aeroallergens. Desensitization of FceRI-bearing mast cells and basophils, accompanied by decreased activity for degranulation and anaphylactic reactions, is observed early after treatment. This effect could be mediated by the up-regulation of the histamine type 2 receptor, which has a suppressive effect on the activation of mast cells and basophils (136). As the therapy progresses, IgG-dependent inhibition of mast cell/basophil activation might contribute to sustaining inhibition of mast cell/basophil activity. In this regard, it has been shown that specific-IgE levels in blood progressively decrease during allergen immunotherapy. On the 
contrary, the titters of allergen-specific IgG4 antibodies increases over time (137-142). This change in balance is thought to be the consequence of increased IL-10 production (140), which can drive allergen-specific B cells to produce IgG4 at the expense of IgE secretion (143). Although the exact clinical consequences of these changes remain unclear, it has been suggested that IgG4 can sequester antigen, thereby limiting its availability for cross-linking of receptor-bound IgE. Alternatively, IgG4 can co-stimulate the inhibitory IgG receptor Fc $\gamma$ RIIb, which negatively regulates FceRI signaling and cell activation (144).

Phenotypic and functional changes in the allergen-specific $\mathrm{T}$ cell response have been observed in the peripheral blood and nasal mucosa of treated patients. These changes included diminished production of Th2 cytokines (IL-4, IL-13, IL-5) by allergen-specific $\mathrm{T}$ cells (142-148) and elevated numbers of allergen-induced Foxp $3^{+} \mathrm{CD} 25^{+}$Tregs expressing IL-10 and TGF-beta $(139,142,146,149-152)$. Whereas, the exact mechanisms through which allergen immunotherapy drives inhibition, deletion, exhaustion, replacement, or reprogramming of $\mathrm{T}$ cells remain elusive, changes in the cytokine milieu could partially account for these changes. For example, allergen immunotherapy triggers IL-10 induction by multiple cell types $(138,140,153,154)$. In turn, IL-10 can control Th2 cell-mediated allergic inflammation by both direct and indirect mechanisms. On the one hand, intrinsic IL-10 signaling may limit Th2 cell responses by directly inducing Th2 cell death (155). On the other hand, IL-10 might prevent Th2 cell expansion by downregulating antigen presentation by reducing MHCII class II expression $(156,157)$ or via IgG4-mediated inhibition of IgEfacilitated allergen presentation $(140,158-160)$. The subsequent reduction in the production of Th2 cytokines, most crucially in IL-4, could favor the differentiation of allergen-specific, IL10-producing inducible Tregs by allowing TGF-beta-dependent up-regulation of FOXP3 in responding T cells (92-95). Thus, initiating a positive feedback loop of IL-10 signaling and Tregmediated immunosuppression that ultimately suppresses the differentiation and function of newly formed allergen-specific Th2 cells $(149,161)$.

In current clinical practice in the United States, immunotherapy is delivered either subcutaneously or sublingually. Additionally, other methods of allergen delivery are being tested for improving outcome.

\section{Subcutaneous Immunotherapy (SCIT)}

Subcutaneous immunotherapy (SCIT), also known as allergy shots involves receiving subcutaneous injections of a particular aeroallergen that has been identified to cause the allergic reaction. Allergen identification is based on the presence of IgE antibodies specific to that allergen (162). Injectable allergen extracts are available to treat allergies triggered by common airborne allergens such as pollen, mold, dust mites, and animal dander.

SCIT treatment consists of two phases: During the Build-up phase, the antigen is given frequently (one to two times per week) in gradually increasing doses until achieving an effective targeted dose (that reduce disease severity from natural exposure). This phase usually lasts 3-6 months. During the maintenance phase, the targeted dose of allergen is injected every 3-4 weeks for at least 3-5 years. Allergy shots are recommended for people with allergy symptoms who do not respond well to usual mediations, have significant side effects from their mediation, want to reduce the long-term use of allergy medication, or for whom allergies might become life-threatening (8). Although allergen immunotherapy is generally safe, it can have adverse reactions, including anaphylaxis $(163,164)$. For that reason, each injection is administered in a setting with trained professionals and equipment to treat anaphylaxis (8). Further, it is essential to identify any patient characteristics (such as severe uncontrolled asthma) that may increase the risk of a severe reaction (165).

\section{Sublingual Immunotherapy (SLIT)}

SLIT involves administering the allergens in a tablet form under the tongue, generally on a daily basis. Sublingual tablets are intended for the treatment of allergic rhinitis and allergic asthma. This therapeutic approach is available for different species of grass pollen and dust mites. SLIT can achieve a significant clinical improvement but shows less efficacy than SCIT, which offers earlier and robust clinical effects and induces systemic changes (166-169). SLIT only provides local changes in the oral mucosa and regional lymph nodes $(170,171)$. The significant advantage of SLIT over SCIT is its safety profile, which allows for administering this treatment outside of the medical setting after the first dose $(131,172)$. Still, as for the possibility of severe allergic reactions from SLIT, an epinephrine auto-injector is usually prescribed to treat potential severe reactions at home.

\section{Future Approaches in Allergen Immunotherapy}

Although SCIT and SLIT are efficacious in that both offer significant clinical improvements in allergic and asthma symptoms, the adherence with the current regimens is low. Most likely because of the frequency of administrations and the long duration of the therapeutic courses. Thus, there is a need for more effective allergen immunotherapy strategies, especially for patients with refractory allergic disease or those who suffer adverse drug reactions.

One of the novel approaches includes using adjuvants such as Toll-like receptor (TLR) agonists. Lipopolysaccharide (LPS), also known as endotoxin, is a major component of Gramnegative bacteria that activates the innate immune response through TLR4. Exposure to airborne allergens containing endotoxin protects against asthma by suppressing the Th2 cell differentiation program in allergen-specific T cells (173-175). In this regard, monophosphoryl Lipid A (MPL), which is a TLR4 agonist, being a derivate of Lipid A from LPS that triggers a moderate inflammatory reaction $(176,177)$, have been evaluated in allergen immunotherapy. Compared to conventional allergen desensitization strategies, MPL immunotherapy show lasting clinical benefits even when administered in shorter courses (178-186). These results are certainly promising and encourage further controlled studies to evaluate clinical and immunological measurements and long-term efficacy.

Outside of TLR4, other agonists targeting alternative TLRs are being investigated in the context of allergen immunotherapy, with components targeting TLR9, TLR8, and TLR7. TLR9 
agonists have been shown to reduce allergic symptoms and modulate the immune response to allergens when administered as an adjuvant in allergen immunotherapy (187-189). Despite promising data, clinical trials have not yet progressed beyond initial studies. TLR7 agonists are currently being evaluated for their safety in the context of allergen immunotherapy (190-193). Future studies will determine whether those are promising adjuvants.

Finally, other routes of allergen administration have been tested. Intralymphatic immunotherapy has shown favorable results in shorten treatment duration. Hence, it might offer an alternative approach to improving allergen immunotherapy adherence and success (194). Intralymphatic immunotherapy involves the application of the allergen directly into the lymph nodes. The whole treatment consists of three ultrasoundguided injections into the inguinal lymph nodes 1 month apart. Although the clinical results are favorable, more extensive studies are needed to support long-term effectiveness.

\section{FUTURE THERAPEUTIC TARGETS: Tfh CELLS IN ASTHMA}

Experimental mouse models of allergic asthma have been instrumental in investigating the mechanisms underlying the initiation and maintenance of allergen-specific Th2 cell responses. Using these preclinical models, it has been shown that the development of allergic Th2 cell responses is more complex than initially expected. During the initial sensitization through the intranasal (i.n.) route, lung-migratory dendritic cells traffic into the lung-draining lymph nodes to prime allergenspecific $\mathrm{CD}^{+}{ }^{+} \mathrm{T}$ cells $(3,195)$. Importantly, however, this initial exposure does not typically result in the accumulation of effector allergen-specific Th2 cells in the airways $(1,3)$. Instead, allergen sensitization triggers a strongly biased Tfh cell response that is restricted to the lung-draining lymph nodes $(1,3,196)$.

Tfh cell development depends on the expression of the transcription factor $\mathrm{Bcl6}$, which functions as a transcriptional repressor that prevents the acquisition of $\mathrm{T}$ effector programs, thereby facilitating Tfh cell differentiation (197-199). However, the capacity of Bcl6 to repress alternative T effector fates is not absolute. As such, whereas Tfh cells were initially characterized as IL-21-producing cells $(198,199)$, they are more plastic than expected and can initiate secondary differentiation programs and secrete Th1 (200-202), Th2 (3, 203), and Th17 (204) effectorlike cytokines when developing in high polarizing environments. Correspondingly, work by us (3, 205), and others (10-12, 16, 206-208), show that Tfh cells can produce large amounts of Th2 cytokines, including IL-4 and IL-13, in response to allergens and helminths. Notably, while early studies considered that Th2 cells

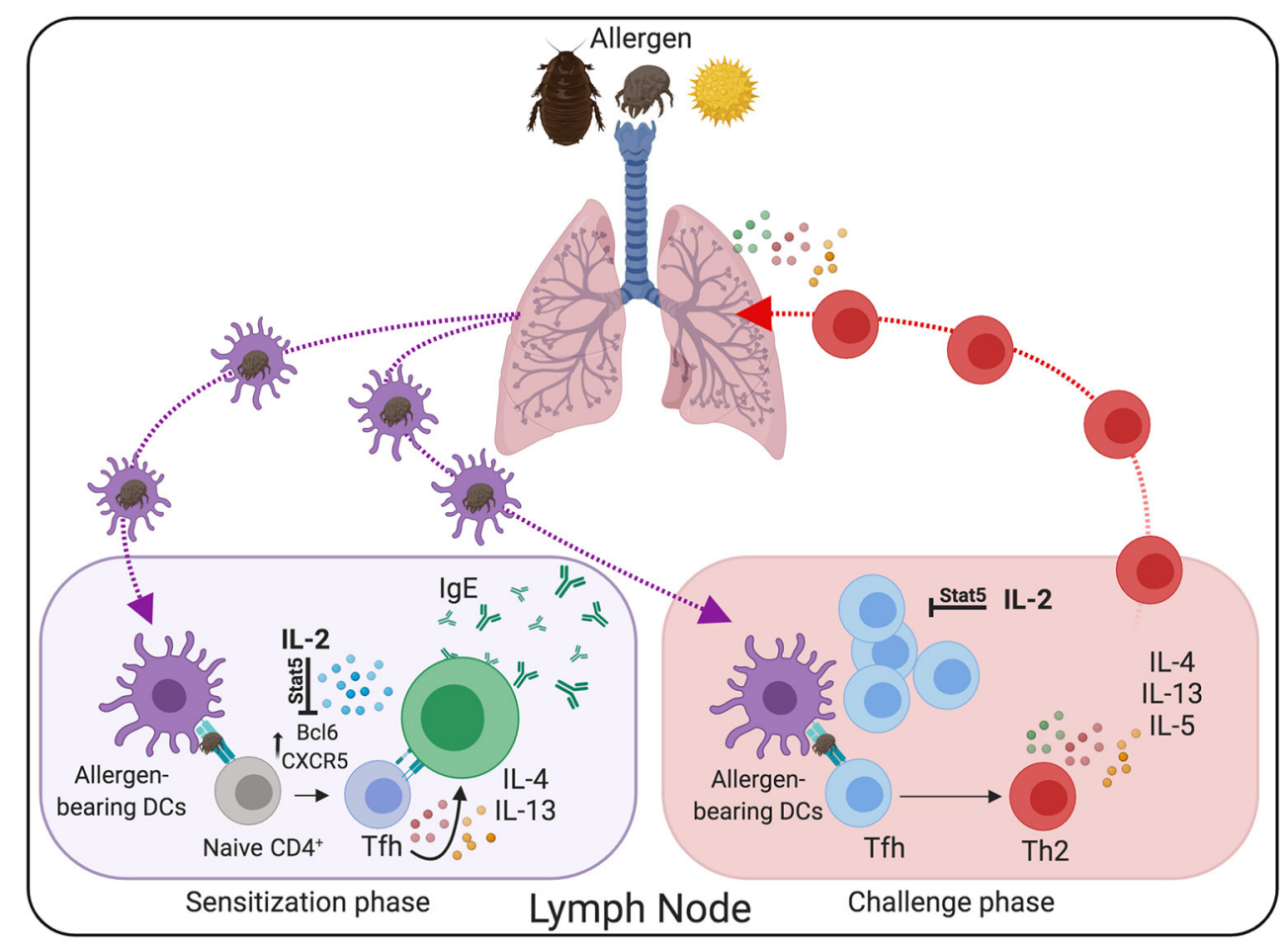

FIGURE 2 | Tfh cells are critical mediators in the pathogenesis of allergic asthma. During the sensitization phase, lung-migratory DC primed allergen-specific "Type 2" Tfh cell responses in the lung-draining lymph node. Through the interaction with B cells, Type-2 Tfh cells promote IgE secretion. Following re-challenge, Tfh cells differentiate into conventional effector Th2 cells that subsequently migrate to the lung and promote allergic airway inflammation. Treatment with rlL-2 has the potential to prevent Tfh cells differentiation and maintenance, thereby reducing asthma pathogenesis. 
were the primary source of type 2 cytokines, it is increasingly accepted that Th cells, and not effector Th2 cells, are the main providers of IL-4 and IL-13 during the sensitization phase (3, 16). Furthermore, more recent data demonstrate that allergenspecific Tfh cells are critical mediators in the pathogenesis of allergic asthma (Figure 2). For example, IL-4/IL-13 producing Tfh cells are critical for the sustained production of high-affinity, allergen-specific $\operatorname{IgE}(1,10,16)$, which, as aforementioned, plays a crucial role in asthma pathogenesis. In addition, using an HDM sensitization and challenge model of asthma, we have recently found that type- 2 Tfh cells survive in the lymph nodes for extended periods as memory cells and have the unique ability to give rise to effector Th2 cells upon allergen rechallenge (3). Combining fate-mapping and adoptive transfer experiments, we demonstrated that allergen-specific Tfh cells generated during the sensitization phase were the precursors of effector Th2 cells found in the lung after secondary challenge. Supporting the role of Tfh cells as progenitors of Th2 cells, depletion of Tfh cells during the sensitization phase prevented the accumulation of effector Th2 cells in the airways after challenge, thereby inhibiting asthma pathogenesis. Thus, our work establishes the lineage flexibility of Tfh cells in allergic disease and identifies these cells as a crucial long-term reservoir of Th2 cell progenitors.

All these studies collectively show a critical function of Tfh cells in allergic asthma pathogenesis, thus highlighting Tfh cells as an attractive target for the suppression of $\operatorname{IgE}$ responses and Th2 cell-mediated allergic inflammation. Unfortunately, there are currently no therapies to selectively target Tfh cells in vivo. Thus, a better understanding of the cellular and molecular mechanisms that control allergen-specific Tfh cell development and function will be critical for designing new therapeutic approaches to prevent Tfh-cell-mediated pathology in asthmatic patients. Interestingly, a large body of evidence indicates that IL-2 is a potent inhibitor of Tfh cells $(3,209-$ 214). IL-2/STAT5 signaling prevents Tfh cell differentiation

\section{REFERENCES}

1. Leomicronn B. $\mathrm{T}$ cells in allergic asthma: key players beyond the Th2 pathway. Curr Allergy Asthma Rep. (2017) 17:43. doi: $10.1007 /$ s11882-017-0714-1

2. Boonpiyathad T, Sozener ZC, Satitsuksanoa P, Akdis CA. Immunologic mechanisms in asthma. Semin Immunol. (2019) 46:101333. doi: 10.1016/j.smim.2019.101333

3. Ballesteros-Tato A, Randall TD, Lund FE, Spolski R, Leonard WJ, Leon B. T Follicular helper cell plasticity shapes pathogenic T helper 2 cellmediated immunity to inhaled house dust mite. Immunity. (2016) 44:25973. doi: 10.1016/j.immuni.2015.11.017

4. Hossny E, Rosario N, Lee BW, Singh M, El-Ghoneimy D, Soh JY, et al. Le Souef, The use of inhaled corticosteroids in pediatric asthma: update. World Allergy Organ J. (2016) 9:26. doi: 10.1186/s40413-016-0117-0

5. Barnes PJ. Inhaled corticosteroids. Pharmaceuticals. (2010) 3:514-40. doi: 10.3390/ph3030514

6. Barnes PJ. Corticosteroid resistance in patients with asthma and chronic obstructive pulmonary disease. J Allergy Clin Immunol. (2013) 131:63645. doi: 10.1016/j.jaci.2012.12.1564 by repressing the expression of Bcl6, the master regulator of Tfh cells. As a consequence of the inhibitory effect of IL2 , Tfh cells fail to differentiate and are efficiently depleted after exogenous recombinant IL-2 treatment $(3,212,214-$ 217). Importantly, subcutaneous administration of low-dose recombinant human IL-2 r-IL2, (Aldesleukin/Proleukin) has potent immunosuppressive effects in patients with autoimmune disorders and can be safely administered to humans (217-220). In agreement with the role of IL-2 as an "anti-Tfh" agent, treatment of active Systemic Lupus Erythematosus (SLE) patients with low-dose rIL-2 resulted in reduced frequencies of Tfh cells in a recent clinical study by Jing $\mathrm{He}$ and colleagues (217), hence evidencing the therapeutic potential of IL-2 to prevent unwanted Tfh cell responses (Figure 2). Given the efficacy and safety of the low-dose IL-2- treatments and the putative role of Tfh cells in asthma pathogenesis, IL-2-based therapies, alone or in combination with other strategies, could represent a promising therapeutic approach to deplete allergen-specific Tfh cells and prevent allergic asthma pathogenesis.

\section{AUTHOR CONTRIBUTIONS}

All authors listed have made a substantial, direct and intellectual contribution to the work, and approved it for publication.

\section{FUNDING}

This work was supported by the University of Alabama at Birmingham (UAB), the National Institutes of Health grant 2R01AI116584 to BL and the National Institutes of Health grant R01AI150664 to AB-T.

\section{ACKNOWLEDGMENTS}

Figures were created with BioRender.com.
7. Doroudchi A, Pathria M, Modena BD. Asthma biologics: Comparing trial designs, patient cohorts and study results. Ann Allergy Asthma Immunol. (2020) 124:44-56. doi: 10.1016/j.anai.2019.10.016

8. Cox L, Nelson H, Lockey R, Calabria C, Chacko T, Finegold I, et al. Allergen immunotherapy: a practice parameter third update. J Allergy Clin Immunol. (2011) 127:S1-55. doi: 10.1016/j.jaci.2010.09.034

9. Masuda S, Fujisawa T, Katsumata H, Atsuta J, Iguchi K. High prevalence and young onset of allergic rhinitis in children with bronchial asthma. Pediatr Allergy Immunol. (2008) 19:517-22. doi: 10.1111/j.1399-3038.2007.00675.x

10. Kobayashi T, Iijima K, Dent AL, Kita H. Follicular helper T cells mediate IgE antibody response to airborne allergens. J Allergy Clin Immunol. (2017) 139:300-13.e7. doi: 10.1016/j.jaci.2016.04.021

11. Meli AP, Fontes G, Leung Soo C, King IL. T Follicular helper cell-derived IL-4 is required for IgE production during intestinal helminth infection. $J$ Immunol. (2017) 199:244-52. doi: 10.4049/jimmunol.1700141

12. Noble, Zhao J. Follicular helper T cells are responsible for IgE responses to Der p 1 following house dust mite sensitization in mice. Clin Exp Allergy. (2016) 46:1075-82. doi: 10.1111/cea.12750

13. Dolence JJ, Kobayashi T, Iijima K, Krempski J, Drake LY, Dent AL, et al. Airway exposure initiates peanut allergy by involving the IL-1 pathway and 
T follicular helper cells in mice. J Allergy Clin Immunol. (2018) 142:114458.e8. doi: 10.1016/j.jaci.2017.11.020

14. Liang HE, Reinhardt RL, Bando JK, Sullivan BM, Ho IC, Locksley RM. Divergent expression patterns of IL-4 and IL-13 define unique functions in allergic immunity. Nat Immunol. (2011) 13:58-66. doi: 10.1038/ni.2182

15. Morita R, Schmitt N, Bentebibel SE, Ranganathan R, Bourdery L, Zurawski G, et al. Human blood CXCR5 $(+)$ CD4(+) T cells are counterparts of $\mathrm{T}$ follicular cells and contain specific subsets that differentially support antibody secretion. Immunity. (2011) 34:10821. doi: 10.1016/j.immuni.2010.12.012

16. Gowthaman U, Chen JS, Zhang B, Flynn WF, Lu Y, Song W, et al. Identification of a $\mathrm{T}$ follicular helper cell subset that drives anaphylactic IgE. Science. (2019) 365:eaaw6433. doi: 10.1126/science.aaw6433

17. Stone KD, Prussin C, Metcalfe DD. IgE, mast cells, basophils, and eosinophils. J Allergy Clin Immunol. (2010) 125:S7380. doi: 10.1016/j.jaci.2009.11.017

18. Suzuki R, Leach S, Liu W, Ralston E, Scheffel J, Zhang W, et al. Molecular editing of cellular responses by the high-affinity receptor for IgE. Science. (2014) 343:1021-5. doi: 10.1126/science.1246976

19. Wang J, Lin J, Bardina L, Goldis M, Nowak-Wegrzyn A, Shreffler WG, et al. Correlation of IgE/IgG4 milk epitopes and affinity of milk-specific IgE antibodies with different phenotypes of clinical milk allergy. J Allergy Clin Immunol. (2010) 125:695-702. doi: 10.1016/j.jaci.2009.12.017

20. Oettgen HC, Geha RS. IgE regulation and roles in asthma pathogenesis. $J$ Allergy Clin Immunol. (2001) 107:429-40. doi: 10.1067/mai.2001.113759

21. Woltmann G, McNulty CA, Dewson G, Symon FA, Wardlaw AJ. Interleukin13 induces PSGL-1/P-selectin-dependent adhesion of eosinophils, but not neutrophils, to human umbilical vein endothelial cells under flow. Blood. (2000) 95:3146-52. doi: 10.1182/blood.V95.10.3146.010k24_3146_3152

22. Johansson MW, Annis DS, Mosher DF. alpha(M)beta(2) integrin-mediated adhesion and motility of IL-5-stimulated eosinophils on periostin. Am J Respir Cell Mol Biol. (2013) 48:503-10. doi: 10.1165/rcmb.2012-0150OC

23. Bochner BS, Klunk DA, Sterbinsky SA, Coffman RL, Schleimer RP. IL-13 selectively induces vascular cell adhesion molecule-1 expression in human endothelial cells. J Immunol. (1995) 154:799-803.

24. Li L, Xia Y, Nguyen A, Lai YH, Feng L, Mosmann TR, et al. Effects of Th2 cytokines on chemokine expression in the lung: IL-13 potently induces eotaxin expression by airway epithelial cells. J Immunol. (1999) 162:2477-87.

25. Dubois GR, Schweizer RC, Versluis C, Bruijnzeel-Koomen CA, Bruijnzeel PL. Human eosinophils constitutively express a functional interleukin-4 receptor: interleukin-4 -induced priming of chemotactic responses and induction of PI-3 kinase activity. Am J Respir Cell Mol Biol. (1998) 19:6919. doi: 10.1165/ajrcmb.19.4.3208

26. Dubois GR, Bruijnzeel-Koomen CA, Bruijnzeel PL. IL-4 induces chemotaxis of blood eosinophils from atopic dermatitis patients, but not from normal individuals. J Invest Dermatol. (1994) 102:843-6. doi: 10.1111/1523-1747.ep12382362

27. Schleimer RP, Sterbinsky SA, Kaiser J, Bickel CA, Klunk DA, Tomioka K, et al., McIntyre BW, et al. IL-4 induces adherence of human eosinophils and basophils but not neutrophils to endothelium. Association with expression of VCAM-1. J Immunol. (1992) 148:1086-92.

28. Grunig G, Warnock M, Wakil AE, Venkayya R, Brombacher F, Rennick DM, et al. Requirement for IL-13 independently of IL-4 in experimental asthma. Science. (1998) 282:2261-3. doi: 10.1126/science.282.5397.2261

29. Wills-Karp M, Luyimbazi J, Xu X, Schofield B, Neben TY, Karp CL, et al. Interleukin-13: central mediator of allergic asthma. Science. (1998) 282:225861. doi: $10.1126 /$ science. 282.5397 .2258

30. Takayama G, Arima K, Kanaji T, Toda S, Tanaka H, Shoji S, et al. Periostin: a novel component of subepithelial fibrosis of bronchial asthma downstream of IL-4 and IL-13 signals. J Allergy Clin Immunol. (2006) 118:98-104. doi: 10.1016/j.jaci.2006.02.046

31. McBrien CN, Menzies-Gow A. The biology of eosinophils and their role in asthma. Front Med. (2017) 4:93. doi: 10.3389/fmed.2017.00093

32. Shi H, Qin S, Huang G, Chen Y, Xiao C, Xu H, et al. Infiltration of eosinophils into the asthmatic airways caused by interleukin 5. Am J Respir Cell Mol Biol. (1997) 16:220-4. doi: 10.1165/ajrcmb.16.3.9070605

33. Lee JJ, Dimina D, Macias MP, Ochkur SI, McGarry MP, O'Neill KR, et al. Defining a link with asthma in mice congenitally deficient in eosinophils. Science. (2004) 305:1773-6. doi: 10.1126/science.10 99472

34. Shen HH, Ochkur SI, McGarry MP, Crosby JR, Hines EM, Borchers MT, et al. A causative relationship exists between eosinophils and the development of allergic pulmonary pathologies in the mouse. J Immunol. (2003) 170:3296305. doi: 10.4049/jimmunol.170.6.3296

35. Justice JP, Borchers MT, Crosby JR, Hines EM, Shen HH, Ochkur SI, et al. Ablation of eosinophils leads to a reduction of allergen-induced pulmonary pathology. Am J Physiol Lung Cell Mol Physiol. (2003) 284:L16978. doi: 10.1152/ajplung.00260.2002

36. Mattes J, Yang M, Mahalingam S, Kuehr J, Webb DC, Simson L, et al. Intrinsic defect in $\mathrm{T}$ cell production of interleukin (IL)-13 in the absence of both IL-5 and eotaxin precludes the development of eosinophilia and airways hyperreactivity in experimental asthma. J Exp Med. (2002) 195:143344. doi: 10.1084/jem.20020009

37. Humbles AA, Lloyd CM, McMillan SJ, Friend DS, Xanthou G, McKenna EE, et al. A critical role for eosinophils in allergic airways remodeling. Science. (2004) 305:1776-9. doi: 10.1126/science.1100283

38. Kay AB, Phipps S, Robinson DS. A role for eosinophils in airway remodelling in asthma. Trends Immunol. (2004) 25:477-82. doi: 10.1016/j.it.2004.07.006

39. Petta I, Dejager L, Ballegeer M, Lievens S, Tavernier J, De Bosscher $\mathrm{K}$, et al. The interactome of the glucocorticoid receptor and its influence on the actions of glucocorticoids in combatting inflammatory and infectious diseases. Microbiol Mol Biol Rev. (2016) 80:495-522. doi: 10.1128/MMBR.00064-15

40. Klassen C, Karabinskaya A, Dejager L, Vettorazzi S, Van Moorleghem J, Luhder F, et al. Airway epithelial cells are crucial targets of glucocorticoids in a mouse model of allergic asthma. J Immunol. (2017) 199:4861. doi: 10.4049/jimmunol.1601691

41. Schwiebert LM, Stellato C, Schleimer RP. The epithelium as a target of glucocorticoid action in the treatment of asthma. Am J Respir Crit Care Med. (1996) 154:S16-9. doi: 10.1164/ajrccm/154.2_Pt_2.S16

42. Surjit M, Ganti KP, Mukherji A, Ye T, Hua G, Metzger D, et al. Widespread negative response elements mediate direct repression by agonist-liganded glucocorticoid receptor. Cell. (2011) 145:224-41. doi: 10.1016/j.cell.2011.03.027

43. Lim HW, Uhlenhaut NH, Rauch A, Weiner J, Hubner S, Hubner N, et al. Genomic redistribution of GR monomers and dimers mediates transcriptional response to exogenous glucocorticoid in vivo. Genome Res. (2015) 25:836-44. doi: 10.1101/gr.188581.114

44. Schiller BJ, Chodankar R, Watson LC, Stallcup MR, Yamamoto KR. Glucocorticoid receptor binds half sites as a monomer and regulates specific target genes. Genome Biol. (2014) 15:418. doi: 10.1186/s13059-014-0418-y

45. Rhen T, Cidlowski JA. Antiinflammatory action of glucocorticoidsnew mechanisms for old drugs. N Engl J Med. (2005) 353:171123. doi: 10.1056/NEJMra050541

46. De Bosscher K, Vanden Berghe W, Haegeman G. The interplay between the glucocorticoid receptor and nuclear factor-kappaB or activator protein1: molecular mechanisms for gene repression. Endocr Rev. (2003) 24:488522. doi: 10.1210/er.2002-0006

47. Bakakos A, Loukides S, Bakakos P. Severe eosinophilic asthma. J Clin Med. (2019) 8:1375. doi: $10.3390 / \mathrm{jcm} 8091375$

48. MacGlashan DW, Bochner BS, Adelman DC, Jardieu PM, Togias A, McKenzie-White J, et al. Down-regulation of Fc(epsilon)RI expression on human basophils during in vivo treatment of atopic patients with anti-IgE antibody. J Immunol. (1997) 158:1438-45.

49. Chang TW, Shiung YY. Anti-IgE as a mast cell-stabilizing therapeutic agent. J Allergy Clin Immunol. (2006) 117:1203-12. doi: 10.1016/j.jaci.2006.04.005

50. Humbert M, Busse W, Hanania NA, Lowe PJ, Canvin J, Erpenbeck VJ, et al. Omalizumab in asthma: an update on recent developments. J Allergy Clin Immunol Pract. (2014) 2:525-36.e1. doi: 10.1016/j.jaip.2014.03.010

51. Ali AK, Hartzema AG. Assessing the association between omalizumab and arteriothrombotic events through spontaneous adverse event reporting. J Asthma Allergy. (2012) 5:1-9. doi: 10.2147/JAA.S 29811

52. Patterson MF, Borish L, Kennedy JL. The past, present, and future of monoclonal antibodies to IL-5 and eosinophilic asthma: a review. J Asthma Allergy. (2015) 8:125-34. doi: 10.2147/JAA.S74178 
53. Laviolette M, Gossage DL, Gauvreau G, Leigh R, Olivenstein R, Katial R, et al. Effects of benralizumab on airway eosinophils in asthmatic patients with sputum eosinophilia. I Allergy Clin Immunol. (2013) 132:1086-96.e5. doi: 10.1016/j.jaci.2013.0 5.020

54. Kolbeck R, Kozhich A, Koike M, Peng L, Andersson CK, Damschroder MM, et al. MEDI-563, a humanized anti-IL-5 receptor alpha mAb with enhanced antibody-dependent cell-mediated cytotoxicity function. J Allergy Clin Immunol. (2010) 125:1344-53.e2. doi: 10.1016/j.jaci.2010.04.004

55. Nair P, Pizzichini MM, Kjarsgaard M, Inman MD, Efthimiadis A, Pizzichini E, et al. Mepolizumab for prednisone-dependent asthma with sputum eosinophilia. $N$ Engl J Med. (2009) 360:985-93. doi: 10.1056/NEJMoa0805435

56. Haldar P, Brightling CE, Hargadon B, Gupta S, Monteiro W, Sousa A, et al. Mepolizumab and exacerbations of refractory eosinophilic asthma. $N$ Engl J Med. (2009) 360:973-84. doi: 10.1056/NEJMoa0808991

57. Pavord ID, Korn S, Howarth P, Bleecker ER, Buhl R, Keene ON, et al. Mepolizumab for severe eosinophilic asthma (DREAM): a multicentre, double-blind, placebo-controlled trial. Lancet. (2012) 380:651-9. doi: 10.1016/S0140-6736(12)60988-X

58. Ortega HG, Liu MC, Pavord ID, Brusselle GG, FitzGerald JM, Chetta A, et al. Mepolizumab treatment in patients with severe eosinophilic asthma. $N$ Engl J Med. (2014) 371:1198-207. doi: 10.1056/NEJMoa1403290

59. Ortega HG, Yancey SW, Mayer B, Gunsoy NB, Keene ON, Bleecker $\mathrm{ER}$, et al. Severe eosinophilic asthma treated with mepolizumab stratified by baseline eosinophil thresholds: a secondary analysis of the DREAM and MENSA studies. Lancet Respir Med. (2016) 4:549-56. doi: 10.1016/S2213-2600(16)30031-5

60. Bel EH, Wenzel SE, Thompson PJ, Prazma CM, Keene ON, Yancey SW, et al. Oral glucocorticoid-sparing effect of mepolizumab in eosinophilic asthma. $N$ Engl J Med. (2014) 371:1189-97. doi: 10.1056/NEJMoa1403291

61. Yancey SW, Bradford ES, Keene ON. Disease burden and efficacy of mepolizumab in patients with severe asthma and blood eosinophil counts of $>/=150-300$ cells/muL. Respir Med. (2019) 151:139-41. doi: 10.1016/j.rmed.2019.04.008

62. Castro M, Mathur S, Hargreave F, Boulet LP, Xie F, Young J, et al. Res-5study, reslizumab for poorly controlled, eosinophilic asthma: a randomized, placebo-controlled study. Am J Respir Crit Care Med. (2011) 184:112532. doi: 10.1164/rccm.201103-0396OC

63. Castro M, Wenzel SE, Bleecker ER, Pizzichini E, Kuna P, Busse WW, et al. Benralizumab, an anti-interleukin 5 receptor alpha monoclonal antibody, versus placebo for uncontrolled eosinophilic asthma: a phase 2 b randomised dose-ranging study. Lancet Respir Med. (2014) 2:87990. doi: 10.1016/S2213-2600(14)70201-2

64. Castro M, Zangrilli J, Wechsler ME, Bateman ED, Brusselle GG, Bardin P, et al. Reslizumab for inadequately controlled asthma with elevated blood eosinophil counts: results from two multicentre, parallel, double-blind, randomised, placebo-controlled, phase 3 trials. Lancet Respir Med. (2015) 3:355-66. doi: 10.1016/S2213-2600(15)00042-9

65. Bjermer L, Lemiere C, Maspero J, Weiss S, Zangrilli J, Germinaro M. Reslizumab for inadequately controlled asthma with elevated blood eosinophil levels: a randomized phase 3 study. Chest. (2016) 150:78998. doi: 10.1016/j.chest.2016.03.032

66. Bleecker ER, FitzGerald JM, Chanez P, Papi A, Weinstein SF, Barker P, et al. Efficacy and safety of benralizumab for patients with severe asthma uncontrolled with high-dosage inhaled corticosteroids and long-acting beta2-agonists (SIROCCO): a randomised, multicentre, placebo-controlled phase 3 trial. Lancet. (2016) 388:2115-27. doi: 10.1016/S0140-6736(16)31324-1

67. Park HS, Lee SH, Lee SY, Kim MK, Lee BJ, Werkstrom V, et al. Efficacy and safety of benralizumab for korean patients with severe, uncontrolled eosinophilic asthma. Allergy Asthma Immunol Res. (2019) 11:508-18. doi: 10.4168/aair.2019.11.4.508

68. Ibrahim H, O’Sullivan R, Casey D, Murphy J, MacSharry J, Plant BJ, et al. The effectiveness of Reslizumab in severe asthma treatment: a real-world experience. Respir Res. (2019) 20:289. doi: 10.1186/s12931-019-1251-3

69. FitzGerald JM, Bleecker ER, Nair P, Korn S, Ohta K, Lommatzsch M, et al. Goldman, investigators Cs. Benralizumab, an anti-interleukin-5 receptor alpha monoclonal antibody, as add-on treatment for patients with severe, uncontrolled, eosinophilic asthma (CALIMA): a randomised, double-blind, placebo-controlled phase 3 trial. Lancet. (2016) 388:212841. doi: 10.1016/S0140-6736(16)31322-8

70. Nair P, Wenzel S, Rabe KF, Bourdin A, Lugogo NL, Kuna P, et al. Oral glucocorticoid-sparing effect of benralizumab in severe asthma. $N$ Engl J Med. (2017) 376:2448-58. doi: 10.1056/NEJMoa1703501

71. Leckie MJ, Ten Brinke A, Khan J, Diamant Z, O’Connor BJ, Walls CM, et al. Effects of an interleukin-5 blocking monoclonal antibody on eosinophils, airway hyper-responsiveness, and the late asthmatic response. Lancet. (2000) 356:2144-8. doi: 10.1016/S0140-6736(00)03496-6

72. Flood-Page P, Swenson C, Faiferman I, Matthews J, Williams M, Brannick L, et al. International mepolizumab study, a study to evaluate safety and efficacy of mepolizumab in patients with moderate persistent asthma. Am J Respir Crit Care Med. (2007) 176:1062-71. doi: 10.1164/rccm.200701-085OC

73. Kips JC, O’Connor BJ, Langley SJ, Woodcock A, Kerstjens HA, Postma DS, et al. Effect of SCH55700, a humanized anti-human interleukin-5 antibody, in severe persistent asthma: a pilot study. Am J Respir Crit Care Med. (2003) 167:1655-9. doi: 10.1164/rccm.200206-525OC

74. Hanania NA, Korenblat P, Chapman KR, Bateman ED, Kopecky P, Paggiaro $\mathrm{P}$, et al. Efficacy and safety of lebrikizumab in patients with uncontrolled asthma (LAVOLTA I and LAVOLTA II): replicate, phase 3, randomised, double-blind, placebo-controlled trials. Lancet Respir Med. (2016) 4:78196. doi: 10.1016/S2213-2600(16)30265-X

75. Corren J, Lemanske RF, Hanania NA, Korenblat PE, Parsey MV, Arron JR, et al. Lebrikizumab treatment in adults with asthma. N Engl J Med. (2011) 365:1088-98. doi: 10.1056/NEJMoa1106469

76. Scheerens H, Arron JR, Zheng Y, Putnam WS, Erickson RW, Choy $\mathrm{DF}$, et al. The effects of lebrikizumab in patients with mild asthma following whole lung allergen challenge. Clin Exp Allergy. (2014) 44:3846. doi: 10.1111/cea.12220

77. Panettieri RA, Sjobring U, Peterffy A, Wessman P, Bowen K, Piper E, et al. Tralokinumab for severe, uncontrolled asthma (STRATOS 1 and STRATOS 2): two randomised, double-blind, placebo-controlled, phase 3 clinical trials. Lancet Respir Med. (2018) 6:511-25. doi: 10.1016/S2213-2600(18)30184-X

78. Busse WW, Brusselle GG, Korn S, Kuna P, Magnan A, Cohen D, et al. Tralokinumab did not demonstrate oral corticosteroid-sparing effects in severe asthma. Eur Respir J. (2019) 53:1800948. doi: 10.1183/13993003.00948-2018

79. Russell RJ, Chachi L, FitzGerald JM, Backer V, Olivenstein R, Titlestad IL, et al. Effect of tralokinumab, an interleukin-13 neutralising monoclonal antibody, on eosinophilic airway inflammation in uncontrolled moderateto-severe asthma (MESOS): a multicentre, double-blind, randomised, placebo-controlled phase 2 trial. Lancet Respir Med. (2018) 6:499510. doi: 10.1016/S2213-2600(18)30201-7

80. Piper E, Brightling C, Niven R, Oh C, Faggioni R, Poon K, et al. A phase II placebo-controlled study of tralokinumab in moderate-to-severe asthma. Eur Respir J. (2013) 41:330-8. doi: 10.1183/09031936.00223411

81. May RD, Monk PD, Cohen ES, Manuel D, Dempsey F, Davis NH, et al. Preclinical development of CAT-354, an IL-13 neutralizing antibody, for the treatment of severe uncontrolled asthma. Br J Pharmacol. (2012) 166:17793. doi: 10.1111/j.1476-5381.2011.01659.x

82. De Boever EH, Ashman C, Cahn AP, Locantore NW, Overend P, Pouliquen IJ, et al. Efficacy and safety of an anti-IL-13 mAb in patients with severe asthma: a randomized trial. J Allergy Clin Immunol. (2014) 133:98996. doi: 10.1016/j.jaci.2014.01.002

83. Gauvreau GM, Boulet LP, Cockcroft DW, Fitzgerald JM, Carlsten C, Davis $\mathrm{BE}$, et al. Effects of interleukin-13 blockade on allergen-induced airway responses in mild atopic asthma. Am J Respir Crit Care Med. (2011) 183:1007-14. doi: 10.1164/rccm.201008-12100C

84. Kasaian MT, Marquette K, Fish S, DeClercq C, Agostinelli R, Cook TA, et al. An IL-4/IL-13 dual antagonist reduces lung inflammation, airway hyperresponsiveness, and IgE production in mice. Am J Respir Cell Mol Biol. (2013) 49:37-46. doi: 10.1165/rcmb.2012-0500OC

85. Wenzel S, Wilbraham D, Fuller R, Getz EB, Longphre M. Effect of an interleukin-4 variant on late phase asthmatic response to allergen challenge in asthmatic patients: results of two phase 2a studies. Lancet. (2007) 370:1422-31. doi: 10.1016/S0140-6736(07)61600-6 
86. Aerovance Inc. Phase $2 b$ Clinical Trial Results Show Aerovance, Inc.'s Aerovant(TM) is Effective in Patients with Eosinophilic Asthma. BioSpace (2010). Available online at: https://www.prnewswire.com/news-releases/ phase-2b-clinical-trial-results-show-aerovances-aerovant-is-effective-inpatients-with-eosinophilic-asthma-95847899.html

87. Corren J, Busse W, Meltzer EO, Mansfield L, Bensch G, Fahrenholz J, et al. A randomized, controlled, phase 2 study of AMG 317, an IL-4Ralpha antagonist, in patients with asthma. Am J Respir Crit Care Med. (2010) 181:788-96. doi: 10.1164/rccm.200909-1448OC

88. Castro M, Corren J, Pavord ID, Maspero J, Wenzel S, Rabe KF, et al. Dupilumab efficacy and safety in moderate-to-severe uncontrolled asthma. N Engl J Med. (2018) 378:2486-96. doi: 10.1056/NEJMoa1804092

89. Wenzel S, Ford L, Pearlman D, Spector S, Sher L, Skobieranda F, et al. Dupilumab in persistent asthma with elevated eosinophil levels. $N$ Engl J Med. (2013) 368:2455-66. doi: 10.1056/NEJMoa1304048

90. Wenzel S, Castro M, Corren J, Maspero J, Wang L, Zhang B, et al. Dupilumab efficacy and safety in adults with uncontrolled persistent asthma despite use of medium-to-high-dose inhaled corticosteroids plus a long-acting beta2 agonist: a randomised double-blind placebocontrolled pivotal phase $2 \mathrm{~b}$ dose-ranging trial. Lancet. (2016) 388:3144. doi: 10.1016/S0140-6736(16)30307-5

91. Rabe KF, Nair P, Brusselle G, Maspero JF, Castro M, Sher L, et al. Efficacy and safety of dupilumab in glucocorticoid-dependent severe asthma. $N$ Engl J Med. (2018) 378:2475-85. doi: 10.1056/NEJMoa1804093

92. Beal AM, Ramos-Hernandez N, Riling CR, Nowelsky EA, Oliver PM. TGF-beta induces the expression of the adaptor Ndfipl to silence IL-4 production during iTreg cell differentiation. Nat Immunol. (2011) 13:7785. doi: 10.1038/ni.2154

93. Dardalhon V, Awasthi A, Kwon H, Galileos G, Gao W, Sobel RA, et al. IL-4 inhibits TGF-beta-induced Foxp3 + T cells and, together with TGFbeta, generates IL-9+ IL-10+ Foxp3(-) effector T cells. Nat Immunol. (2008) 9:1347-55. doi: 10.1038/ni.1677

94. Hadjur S, Bruno L, Hertweck A, Cobb BS, Taylor B, Fisher AG, et al. IL4 blockade of inducible regulatory $\mathrm{T}$ cell differentiation: the role of Th2 cells, Gata3 and PU.1. Immunol Lett. (2009) 122:3743. doi: 10.1016/j.imlet.2008.11.001

95. Xu L, Kitani A, Strober W. Molecular mechanisms regulating TGF-beta-induced Foxp3 expression. Mucosal Immunol. (2010) 3:230-8. doi: 10.1038/mi.2010.7

96. Bachert C, Mannent L, Naclerio RM, Mullol J, Ferguson BJ, Gevaert P, et al. Effect of subcutaneous dupilumab on nasal polyp burden in patients with chronic sinusitis and nasal polyposis: a randomized clinical trial. JAMA. (2016) 315:469-79. doi: 10.1001/jama.2015.19330

97. Simpson EL, Bieber T, Guttman-Yassky E, Beck LA, Blauvelt A, Cork MJ, et al. Two phase 3 trials of dupilumab versus placebo in atopic dermatitis. $N$ Engl J Med. (2016) 375:2335-48. doi: 10.1056/NEJMoa1610020

98. Thaci D, Simpson EL, Beck LA, Bieber T, Blauvelt A, Papp K, et al. Efficacy and safety of dupilumab in adults with moderate-to-severe atopic dermatitis inadequately controlled by topical treatments: a randomised, placebo-controlled, dose-ranging phase 2b trial. Lancet. (2016) 387:4052. doi: 10.1016/S0140-6736(15)00388-8

99. Godar M, Deswarte K, Vergote K, Saunders M, de Haard H, Hammad $\mathrm{H}$, et al. A bispecific antibody strategy to target multiple type 2 cytokines in asthma. J Allergy Clin Immunol. (2018) 142:1185-93.e4. doi: 10.1016/j.jaci.2018.06.002

100. Ying S, O'Connor B, Ratoff J, Meng Q, Mallett K, Cousins D, et al. Thymic stromal lymphopoietin expression is increased in asthmatic airways and correlates with expression of Th2-attracting chemokines and disease severity. J Immunol. (2005) 174:8183-90. doi: 10.4049/jimmunol.174.12.8183

101. Ying S, O'Connor B, Ratoff J, Meng Q, Fang C, Cousins D, et al. Expression and cellular provenance of thymic stromal lymphopoietin and chemokines in patients with severe asthma and chronic obstructive pulmonary disease. $J$ Immunol. (2008) 181:2790-8. doi: 10.4049/jimmunol.181.4.2790

102. Li Y, Wang W, Lv Z, Li Y, Chen Y, Huang K, et al. Elevated expression of IL-33 and TSLP in the airways of human asthmatics in vivo: a potential biomarker of severe refractory disease. J Immunol. (2018) 200:225362. doi: 10.4049/jimmunol.1701455
103. Shikotra, Choy DF, Ohri CM, Doran E, Butler C, Hargadon B, et al. Increased expression of immunoreactive thymic stromal lymphopoietin in patients with severe asthma. J Allergy Clin Immunol. (2012) 129:104-11.e19. doi: 10.1016/j.jaci.2011.08.031

104. Soumelis V, Reche PA, Kanzler H, Yuan W, Edward G, Homey B, et al. Human epithelial cells trigger dendritic cell mediated allergic inflammation by producing TSLP. Nat Immunol. (2002) 3:673-80. doi: 10.1038/n i805

105. Bleck B, Kazeros A, Bakal K, Garcia-Medina L, Adams A, Liu M, et al. Coexpression of type 2 immune targets in sputum-derived epithelial and dendritic cells from asthmatic subjects. $J$ Allergy Clin Immunol. (2015) 136:619-27.e5. doi: 10.1016/j.jaci.2014.12. 1950

106. Kabata H, Flamar AL, Mahlakoiv T, Moriyama S, Rodewald HR, Ziegler SF, et al. Targeted deletion of the TSLP receptor reveals cellular mechanisms that promote type 2 airway inflammation. Mucosal Immunol. (2020) 13:626-36. doi: 10.1038/s41385-020-0 266-x

107. Tang H, Cao W, Kasturi SP, Ravindran R, Nakaya HI, Kundu K, et al. The T helper type 2 response to cysteine proteases requires dendritic cellbasophil cooperation via ROS-mediated signaling. Nat Immunol. (2010) 11:608-17. doi: 10.1038/ni.1883

108. Nakanishi W, Hiraishi Y, Yamaguchi S, Takamori A, Morita H, Matsumoto K, et al. TSLP receptor is not essential for house dust mite-induced allergic rhinitis in mice. Biochem Biophys Rep. (2016) 7:119-23. doi: 10.1016/j.bbrep.2016.06.003

109. Kale SL, Agrawal K, Gaur SN, Arora N. Cockroach protease allergen induces allergic airway inflammation via epithelial cell activation. Sci Rep. (2017) 7:42341. doi: 10.1038/srep42341

110. Li DQ, Zhang L, Pflugfelder SC, De Paiva CS, Zhang X, Zhao G, et al. Short ragweed pollen triggers allergic inflammation through toll-like receptor 4-dependent thymic stromal lymphopoietin/OX40 ligand/OX40 signaling pathways. J Allergy Clin Immunol. (2011) 128:1318-25.e2. doi: 10.1016/j.jaci.2011.06.041

111. Kouzaki H, O'Grady SM, Lawrence CB, Kita H. Proteases induce production of thymic stromal lymphopoietin by airway epithelial cells through protease-activated receptor-2. J Immunol. (2009) 183:142734. doi: 10.4049/jimmunol.0900904

112. Hiraishi Y, Yamaguchi S, Yoshizaki T, Nambu A, Shimura E, Takamori A, et al. Nakae IL-33 S, IL-25 and TSLP contribute to development of fungal-associated protease-induced innate-type airway inflammation. Sci Rep. (2018) 8:18052. doi: 10.1038/s41598-018-36440-x

113. Halim TY, Krauss RH, Sun AC, Takei F. Lung natural helper cells are a critical source of Th2 cell-type cytokines in protease allergen-induced airway inflammation. Immunity. (2012) 36:451-63. doi: 10.1016/j.immuni.2011.12.020

114. Al-Shami, Spolski R, Kelly J, Keane-Myers A, Leonard WJ. A role for TSLP in the development of inflammation in an asthma model. J Exp Med. (2005) 202:829-39. doi: 10.1084/jem.20050199

115. Zhou, Comeau MR, De Smedt T, Liggitt HD, Dahl ME, Lewis DB, et al. Thymic stromal lymphopoietin as a key initiator of allergic airway inflammation in mice. Nat Immunol. (2005) 6:1047-53. doi: 10.1038/ni1247

116. Zhou, Headley MB, Aye T, Tocker J, Comeau MR, Ziegler SF. Reversal of thymic stromal lymphopoietin-induced airway inflammation through inhibition of Th2 responses. J Immunol. (2008) 181:6557-62. doi: 10.4049/jimmunol.181.9.6557

117. Omori $M$, Ziegler S. Induction of IL-4 expression in CD4(+) $T$ cells by thymic stromal lymphopoietin. J Immunol. (2007) 178:1396404. doi: 10.4049/jimmunol.178.3.1396

118. Ito T, Wang $\mathrm{YH}$, Duramad O, Hori T, Delespesse GJ, Watanabe $\mathrm{N}$, et al. TSLP-activated dendritic cells induce an inflammatory $\mathrm{T}$ helper type 2 cell response through OX40 ligand. J Exp Med. (2005) 202:121323. doi: 10.1084/jem.20051135

119. Wang YH, Ito T, Wang YH, Homey B, Watanabe N, Martin R, et al. Maintenance and polarization of human $\mathrm{TH} 2$ central memory $\mathrm{T}$ cells by thymic stromal lymphopoietin-activated dendritic cells. Immunity. (2006) 24:827-38. doi: 10.1016/j.immuni.2006.03.019 
120. Halim TY, Steer CA, Matha L, Gold MJ, Martinez-Gonzalez I, McNagny $\mathrm{KM}$, et al. Group 2 innate lymphoid cells are critical for the initiation of adaptive $\mathrm{T}$ helper 2 cell-mediated allergic lung inflammation. Immunity. (2014) 40:425-35. doi: 10.1016/j.immuni.2014.01.011

121. Mohapatra, Van Dyken SJ, Schneider C, Nussbaum JC, Liang HE, Locksley RM. Group 2 innate lymphoid cells utilize the IRF4-IL-9 module to coordinate epithelial cell maintenance of lung homeostasis. Mucosal Immunol. (2016) 9:275-86. doi: 10.1038/mi.2015.59

122. Halim TY, Hwang YY, Scanlon ST, Zaghouani H, Garbi N, Fallon PG, et al. Group 2 innate lymphoid cells license dendritic cells to potentiate memory TH2 cell responses. Nat Immunol. (2016) 17:57-64. doi: 10.1038/ni.3294

123. Corren J, Ziegler SF. TSLP: from allergy to cancer. Nat Immunol. (2019) 20:1603-9. doi: 10.1038/s41590-019-0524-9

124. Verstraete K, Peelman F, Braun H, Lopez J, Van Rompaey D, Dansercoer A, et al. Structure and antagonism of the receptor complex mediated by human TSLP in allergy and asthma. Nat Commun. (2017) 8:14937. doi: $10.1038 /$ ncomms 14937

125. Gauvreau GM, O'Byrne PM, Boulet LP, Wang Y, Cockcroft D, Bigler J, et al. Effects of an anti-TSLP antibody on allergen-induced asthmatic responses. $N$ Engl J Med. (2014) 370:2102-10. doi: 10.1056/NEJMoa1402895

126. Corren J, Parnes JR, Wang L, Mo M, Roseti SL, Griffiths JM, et al. Tezepelumab in adults with uncontrolled asthma. N Engl J Med. (2017) 377:936-46. doi: 10.1056/NEJMoa1704064

127. Corren J, Chen S, Callan L, Gil EG. The effect of tezepelumab on hospitalizations and emergency department visits in patients with severe asthma. Ann Allergy Asthma Immunol. (2020) 125:211-4. doi: 10.1016/j.anai.2020.05.020

128. Bousquet J, Lockey R, Malling HJ. Allergen immunotherapy: therapeutic vaccines for allergic diseases. A WHO position paper. J Allergy Clin Immunol. (1998) 102:558-62. doi: 10.1016/S0091-6749(98)70271-4

129. Durham SR, Walker SM, Varga EM, Jacobson MR, O'Brien F, Noble W, et al. Long-term clinical efficacy of grass-pollen immunotherapy. N Engl J Med. (1999) 341:468-75. doi: 10.1056/NEJM199908123410702

130. Walker SM, Pajno GB, Lima MT, Wilson DR, Durham SR. Grass pollen immunotherapy for seasonal rhinitis and asthma: a randomized, controlled trial. J Allergy Clin Immunol. (2001) 107:87-93. doi: 10.1067/mai.2001.112027

131. Canonica GW, Cox L, Pawankar R, Baena-Cagnani CE, Blaiss M, Bonini S, et al. Sublingual immunotherapy: world allergy organization position paper 2013 update. World Allergy Organ J. (2014) 7:6. doi: 10.1186/1939-4551-7-6

132. Moller C, Dreborg S, Ferdousi HA, Halken S, Host A, Jacobsen L, et al. Pollen immunotherapy reduces the development of asthma in children with seasonal rhinoconjunctivitis (the PAT-study). J Allergy Clin Immunol. (2002) 109:251-6. doi: 10.1067/mai.2002.121317

133. Grembiale RD, Camporota L, Naty S, Tranfa CM, Djukanovic R, Marsico SA. Effects of specific immunotherapy in allergic rhinitic individuals with bronchial hyperresponsiveness. Am J Respir Crit Care Med. (2000) 162:204852. doi: 10.1164/ajrccm.162.6.9909087

134. Eng PA, Borer-Reinhold M, Heijnen IA, Gnehm HP. Twelveyear follow-up after discontinuation of preseasonal grass pollen immunotherapy in childhood. Allergy. (2006) 61:198201. doi: 10.1111/j.1398-9995.2006.01011.x

135. Marogna M, Spadolini I, Massolo A, Canonica GW, Passalacqua G. Longlasting effects of sublingual immunotherapy according to its duration: a 15-year prospective study. J Allergy Clin Immunol. (2010) 126:96975. doi: 10.1016/j.jaci.2010.08.030

136. Novak N, Mete N, Bussmann C, Maintz L, Bieber T, Akdis M, et al. Early suppression of basophil activation during allergen-specific immunotherapy by histamine receptor 2. J Allergy Clin Immunol. (2012) 130:11538.e2. doi: 10.1016/j.jaci.2012.04.039

137. Platts-Mills T, Vaughan J, Squillace S, Woodfolk J, Sporik R. Sensitisation, asthma, and a modified Th2 response in children exposed to cat allergen: a population-based cross-sectional study. Lancet. (2001) 357:7526. doi: 10.1016/S0140-6736(00)04168-4

138. Francis JN, James LK, Paraskevopoulos G, Wong C, Calderon MA, Durham $\mathrm{SR}$, et al. Grass pollen immunotherapy: IL-10 induction and suppression of late responses precedes IgG4 inhibitory antibody activity. J Allergy Clin Immunol. (2008) 121:1120-5.e2. doi: 10.1016/j.jaci.2008.01.072
139. Scadding GW, Shamji MH, Jacobson MR, Lee DI, Wilson D, Lima MT, et al. Sublingual grass pollen immunotherapy is associated with increases in sublingual Foxp3-expressing cells and elevated allergen-specific immunoglobulin G4, immunoglobulin A and serum inhibitory activity for immunoglobulin E-facilitated allergen binding to B cells. Clin Exp Allergy. (2010) 40:598-606. doi: 10.1111/j.1365-2222.2010.03462.x

140. Nouri-Aria KT, Wachholz PA, Francis JN, Jacobson MR, Walker SM, Wilcock LK, et al. Grass pollen immunotherapy induces mucosal and peripheral IL-10 responses and blocking IgG activity. J Immunol. (2004) 172:3252-9. doi: 10.4049/jimmunol.172.5.3252

141. James LK, Shamji MH, Walker SM, Wilson DR, Wachholz PA, Francis JN, et al. Long-term tolerance after allergen immunotherapy is accompanied by selective persistence of blocking antibodies. J Allergy Clin Immunol. (2011) 127:509-16.e1-5. doi: 10.1016/j.jaci.2010.12.1080

142. Suarez-Fueyo, Ramos T, Galan A, Jimeno L, Wurtzen PA, Marin A, de Frutos C, et al. Grass tablet sublingual immunotherapy downregulates the TH2 cytokine response followed by regulatory T-cell generation. J Allergy Clin Immunol. (2014) 133:130-8.e1-2. doi: 10.1016/j.jaci.2013.09.043

143. Jeannin P, Lecoanet S, Delneste Y, Gauchat JF, Bonnefoy JY. IgE versus IgG4 production can be differentially regulated by IL-10. J Immunol. (1998) 160:3555-61.

144. James LK, Till SJ. Potential Mechanisms for IgG4 Inhibition of Immediate Hypersensitivity Reactions. Curr Allergy Asthma Rep. (2016) 16:23. doi: 10.1007/s11882-016-0600-2

145. Scadding GW, Eifan AO, Lao-Araya M, Penagos M, Poon SY, Steveling $\mathrm{E}$, et al. Effect of grass pollen immunotherapy on clinical and local immune response to nasal allergen challenge. Allergy. (2015) 70:68996. doi: 10.1111/all.12608

146. Radulovic S, Jacobson MR, Durham SR, Nouri-Aria KT. Grass pollen immunotherapy induces Foxp3-expressing CD4+ CD25+ cells in the nasal mucosa. J Allergy Clin Immunol. (2008) 121:1467-72. doi: 10.1016/j.jaci.2008.03.013

147. Secrist H, Chelen CJ, Wen Y, Marshall JD, Umetsu DT. Allergen immunotherapy decreases interleukin 4 production in CD4+ $\mathrm{T}$ cells from allergic individuals. J Exp Med. (1993) 178:2123-30. doi: 10.1084/jem.178.6.2123

148. Wang CM, Chang CB, Chan MW, Wen ZH, Wu SF. Dust mite allergenspecific immunotherapy increases IL4 DNA methylation and induces Der p-specific T cell tolerance in children with allergic asthma. Cell Mol Immunol. (2018) 15:963-72. doi: 10.1038/cmi.2017.26

149. Jutel M, Akdis M, Budak F, Aebischer-Casaulta C, Wrzyszcz M, Blaser K, et al. IL-10 and TGF-beta cooperate in the regulatory T cell response to mucosal allergens in normal immunity and specific immunotherapy. Eur J Immunol. (2003) 33:1205-14. doi: 10.1002/eji.200322919

150. Sakurai D, Yonekura S, Iinuma T, Sakurai T, Morimoto Y, Mita $\mathrm{Y}$, et al. Sublingual immunotherapy for allergic rhinitis: subjective versus objective tools to evaluate its success. Rhinology. (2016) 54:22130. doi: 10.4193/Rhin15.223

151. Bohle B, Kinaciyan T, Gerstmayr M, Radakovics A, Jahn-Schmid B, Ebner C. Sublingual immunotherapy induces IL-10-producing $\mathrm{T}$ regulatory cells, allergen-specific T-cell tolerance, immune deviation. J Allergy Clin Immunol. (2007) 120:707-13. doi: 10.1016/j.jaci.2007.06.013

152. Wambre E, DeLong JH, James EA, LaFond RE, Robinson D, Kwok WW. Differentiation stage determines pathologic and protective allergen-specific CD4+ T-cell outcomes during specific immunotherapy. J Allergy Clin Immunol. (2012) 129:544-51. doi: 10.1016/j.jaci.2011.08.034

153. Mobs C, Slotosch C, Loffler H, Jakob T, Hertl M, Pfutzner W. Birch pollen immunotherapy leads to differential induction of regulatory $\mathrm{T}$ cells and delayed helper T cell immune deviation. J Immunol. (2010) 184:2194203. doi: 10.4049/jimmunol.0901379

154. Boonpiyathad T, Satitsuksanoa P, Akdis M, Akdis CA. Il-10 producing $\mathrm{T}$ and $\mathrm{B}$ cells in allergy. Semin Immunol. (2019) 44:101326. doi: 10.1016/j.smim.2019.101326

155. Coomes SM, Kannan Y, Pelly VS, Entwistle LJ, Guidi R, Perez-Lloret J, et al. CD4(+) Th2 cells are directly regulated by IL-10 during allergic airway inflammation. Mucosal Immunol. (2017) 10:150-61. doi: 10.1038/mi.2016.47

156. de Waal Malefyt R, Haanen J, Spits H, Roncarolo MG, te Velde A, Figdor C, et al. Interleukin 10 (IL-10) and viral IL-10 strongly reduce antigen-specific 
human $\mathrm{T}$ cell proliferation by diminishing the antigen-presenting capacity of monocytes via downregulation of class II major histocompatibility complex expression. J Exp Med. (1991) 174:915-24. doi: 10.1084/jem.174.4.915

157. Koppelman B, Neefjes JJ, de Vries JE, R. de Waal Malefyt, Interleukin-10 down-regulates MHC class II alphabeta peptide complexes at the plasma membrane of monocytes by affecting arrival and recycling. Immunity. (1997) 7:861-71. doi: 10.1016/S1074-7613(00)80404-5

158. R.J. van Neerven, Wikborg T, Lund G, Jacobsen B, Brinch-Nielsen A, Arnved $\mathrm{J}$, et al. Blocking antibodies induced by specific allergy vaccination prevent the activation of $\mathrm{CD} 4+\mathrm{T}$ cells by inhibiting serum-IgE-facilitated allergen presentation. J Immunol. (1999) 163:2944-52.

159. Holm J, Willumsen N, Wurtzen PA, Christensen LH, Lund K. Facilitated antigen presentation and its inhibition by blocking $\operatorname{IgG}$ antibodies depends on IgE repertoire complexity. J Allergy Clin Immunol. (2011) 127:102937. doi: $10.1016 /$ j.jaci.2011.01.062

160. James LK, Bowen H, Calvert RA, Dodev TS, Shamji MH, Beavil AJ, et al. Allergen specificity of $\operatorname{IgG}(4)$-expressing $B$ cells in patients with grass pollen allergy undergoing immunotherapy. J Allergy Clin Immunol. (2012) 130:663-70 e3. doi: 10.1016/j.jaci.2012.04.006

161. Taylor, Verhagen J, Blaser K, Akdis M, Akdis CA. Mechanisms of immune suppression by interleukin-10 and transforming growth factorbeta: the role of $\mathrm{T}$ regulatory cells. Immunology. (2006) 117:43342. doi: 10.1111/j.1365-2567.2006.02321.x

162. Ansotegui IJ, Melioli G, Canonica GW, Caraballo L, Villa E, Ebisawa $\mathrm{M}$, et al. IgE allergy diagnostics and other relevant tests in allergy, a World Allergy Organization position paper. World Allergy Organ J. (2020) 13:100080. doi: 10.1016/j.waojou.2019.100080

163. Bernstein DI, Epstein T, Murphy-Berendts K, Liss GM. Surveillance of systemic reactions to subcutaneous immunotherapy injections: year 1 outcomes of the ACAAI and AAAAI collaborative study. Ann Allergy Asthma Immunol. (2010) 104:530-5. doi: 10.1016/j.anai.2010.04.008

164. Epstein TG, Liss GM, Murphy-Berendts K, Bernstein DI. Immediate and delayed-onset systemic reactions after subcutaneous immunotherapy injections: ACAAI/AAAAI surveillance study of subcutaneous immunotherapy: year 2. Ann Allergy Asthma Immunol. (2011) 107:426-31.e1. doi: 10.1016/j.anai.2011.05.020

165. Bernstein DI, Wanner M, Borish L, Liss GM, A.A.o.A.A. Immunotherapy Committee, and Immunology, twelve-year survey of fatal reactions to allergen injections and skin testing: 1990-2001. J Allergy Clin Immunol. (2004) 113:1129-36. doi: 10.1016/j.jaci.2004.02.006

166. Eifan AO, Akkoc T, Yildiz A, Keles S, Ozdemir C, Bahceciler NN, et al. Clinical efficacy and immunological mechanisms of sublingual and subcutaneous immunotherapy in asthmatic/rhinitis children sensitized to house dust mite: an open randomized controlled trial. Clin Exp Allergy. (2010) 40:922-32. doi: 10.1111/j.1365-2222.2009.03448.x

167. Keles S, Karakoc-Aydiner E, Ozen A, Izgi AG, Tevetoglu A, Akkoc T, et al. A novel approach in allergen-specific immunotherapy: combination of sublingual and subcutaneous routes. J Allergy Clin Immunol. (2011) 128:80815.e7. doi: 10.1016/j.jaci.2011.04.033

168. Yukselen, Kendirli SG, Yilmaz M, Altintas DU, Karakoc GB. Effect of oneyear subcutaneous and sublingual immunotherapy on clinical and laboratory parameters in children with rhinitis and asthma: a randomized, placebocontrolled, double-blind, double-dummy study. Int Arch Allergy Immunol. (2012) 157:288-98. doi: 10.1159/000327566

169. Quirino T, Iemoli E, Siciliani E, Parmiani S, Milazzo F. Sublingual versus injective immunotherapy in grass pollen allergic patients: a double blind (double dummy) study. Clin Exp Allergy. (1996) 26:125361. doi: 10.1111/j.1365-2222.1996.tb00522.x

170. Mungan D, Misirligil Z, Gurbuz L. Comparison of the efficacy of subcutaneous and sublingual immunotherapy in mite-sensitive patients with rhinitis and asthma-a placebo controlled study. Ann Allergy Asthma Immunol. (1999) 82:485-90. doi: 10.1016/S1081-1206(10)6 $2726-3$

171. Khinchi MS, Poulsen LK, Carat F, Andre C, Hansen AB, Malling HJ. Clinical efficacy of sublingual and subcutaneous birch pollen allergen-specific immunotherapy: a randomized, placebocontrolled, double-blind, double-dummy study. Allergy. (2004) 59:45-53. doi: 10.1046/j.1398-9995.2003.00387.x
172. Calderon MA, Simons FE, Malling HJ, Lockey RF, Moingeon P, Demoly P. Sublingual allergen immunotherapy: mode of action and its relationship with the safety profile. Allergy. (2012) 67:302-11. doi: 10.1111/j.1398-9995.2011.02761.x

173. Bachus H, Kaur K, Papillion AM, Marquez-Lago TT, Yu Z, Ballesteros-Tato A, et al. Impaired tumor-necrosis-factor-alphadriven dendritic cell activation limits lipopolysaccharide-induced protection from allergic inflammation in infants. Immunity. (2019) 50:225-40.e4. doi: 10.1016/j.immuni.2018.11.012

174. Gereda JE, Leung DY, Thatayatikom A, Streib JE, Price MR, Klinnert $\mathrm{MD}$, et al. Relation between house-dust endotoxin exposure, type $1 \mathrm{~T}$-cell development, and allergen sensitisation in infants at high risk of asthma. Lancet. (2000) 355:1680-3. doi: 10.1016/S0140-6736(00)02239-X

175. Stein MM, Hrusch CL, Gozdz J, Igartua C, Pivniouk V, Murray SE, et al. Innate immunity and asthma risk in amish and hutterite farm children. $N$ Engl J Med. (2016) 375:411-21. doi: 10.1056/NEJMoa1508749

176. Baldridge JR, McGowan P, Evans JT, Cluff C, Mossman S, Johnson D, et al. Taking a toll on human disease: toll-like receptor 4 agonists as vaccine adjuvants and monotherapeutic agents. Expert Opin Biol Ther. (2004) 4:1129-38. doi: 10.1517/14712598.4.7.1129

177. Chentouh R, Fitting C, Cavaillon JM. Specific features of human monocytes activation by monophosphoryl lipid A. Sci Rep. (2018) 8:7096. doi: 10.1038/s41598-018-25367-y

178. Drachenberg KJ, Wheeler AW, Stuebner P, Horak F. A well-tolerated grass pollen-specific allergy vaccine containing a novel adjuvant, monophosphoryl lipid A, reduces allergic symptoms after only four preseasonal injections. Allergy. (2001) 56:498-505. doi: 10.1034/j.1398-9995.2001.056006498.x

179. Mothes N, Heinzkill M, Drachenberg KJ, Sperr WR, Krauth MT, Majlesi $\mathrm{Y}$, et al. Allergen-specific immunotherapy with a monophosphoryl lipid A-adjuvanted vaccine: reduced seasonally boosted immunoglobulin E production and inhibition of basophil histamine release by therapy-induced blocking antibodies. Clin Exp Allergy. (2003) 33:1198-208. doi: 10.1046/j.1365-2222.2003.01699.x

180. Patel P, Salapatek AM. Pollinex Quattro: a novel and well-tolerated, ultra short-course allergy vaccine. Expert Rev Vaccines. (2006) 5:61729. doi: 10.1586/14760584.5.5.617

181. Zielen S, Gabrielpillai J, Herrmann E, Schulze J, Schubert R, Rosewich M. Long-term effect of monophosphoryl lipid A adjuvanted specific immunotherapy in patients with grass pollen allergy. Immunotherapy. (2018) 10:529-36. doi: 10.2217/imt-2018-0004

182. DuBuske LM, Frew AJ, Horak F, Keith PK, Corrigan CJ, Aberer W, et al. Ultrashort-specific immunotherapy successfully treats seasonal allergic rhinoconjunctivitis to grass pollen. Allergy Asthma Proc. (2011) 32:23947. doi: 10.2500/aap.2011.32.3453

183. Rosewich M, Girod K, Zielen S, Schubert R, Schulze J. Induction of bronchial tolerance after 1 cycle of monophosphoryl-A-adjuvanted specific immunotherapy in children with grass pollen allergies. Allergy Asthma Immunol Res. (2016) 8:257-63. doi: 10.4168/aair.2016.8.3.257

184. Pfaar O, Barth C, Jaschke C, Hormann K, Klimek L. Sublingual allergen-specific immunotherapy adjuvanted with monophosphoryl lipid A: a phase I/IIa study. Int Arch Allergy Immunol. (2011) 154:33644. doi: $10.1159 / 000321826$

185. Patel P, Holdich T, Fischer von Weikersthal-Drachenberg KJ, Huber B. Efficacy of a short course of specific immunotherapy in patients with allergic rhinoconjunctivitis to ragweed pollen. J Allergy Clin Immunol. (2014) 133:121-9.e1-2. doi: 10.1016/j.jaci.2013.05.032

186. Worm M, Higenbottam T, Pfaar O, Mosges R, Aberer W, Gunawardena $\mathrm{K}$, et al. Randomized controlled trials define shape of dose response for Pollinex Quattro Birch allergoid immunotherapy. Allergy. (2018) 73:181222. doi: $10.1111 /$ all. 13478

187. Creticos PS, Schroeder JT, Hamilton RG, Balcer-Whaley SL, Khattignavong AP, Lindblad R, et al. Immune tolerance network, immunotherapy with a ragweed-toll-like receptor 9 agonist vaccine for allergic rhinitis. N Engl J Med. (2006) 355:1445-55. doi: 10.1056/NEJMoa052916

188. Senti G, Johansen P, Haug S, Bull C, Gottschaller C, Muller P, et al. Use of A-type $\mathrm{CpG}$ oligodeoxynucleotides as an adjuvant in allergen-specific immunotherapy in humans: a phase I/Ila clinical trial. Clin Exp Allergy. (2009) 39:562-70. doi: 10.1111/j.1365-2222.2008.03191.x 
189. Klimek L, Willers J, Hammann-Haenni A, Pfaar O, Stocker H, Mueller P, et al. Assessment of clinical efficacy of CYT003-QbG10 in patients with allergic rhinoconjunctivitis: a phase IIb study. Clin Exp Allergy. (2011) 41:1305-12. doi: 10.1111/j.1365-2222.2011.03783.x

190. Tsitoura D, Ambery C, Price M, Powley W, Garthside S, Biggadike K, et al. Early clinical evaluation of the intranasal TLR7 agonist GSK2245035: use of translational biomarkers to guide dosing and confirm target engagement. Clin Pharmacol Ther. (2015) 98:369-80. doi: 10.1002/cpt.157

191. Ellis AK, Tsitoura DC, Quint D, Powley W, Lee LA. Safety and pharmacodynamics of intranasal GSK2245035, a TLR7 agonist for allergic rhinitis: a randomized trial. Clin Exp Allergy. (2017) 47:1193203. doi: $10.1111 /$ cea.12974

192. Greiff L, Cervin A, Ahlstrom-Emanuelsson C, Almqvist G, Andersson M, Dolata J, et al. Repeated intranasal TLR7 stimulation reduces allergen responsiveness in allergic rhinitis. Respir Res. (2012) 13:53. doi: 10.1186/1465-9921-13-53

193. Greiff L, Ahlstrom-Emanuelsson C, Alenas M, Almqvist G, Andersson M, Cervin A, et al. Biological effects and clinical efficacy of a topical Toll-like receptor 7 agonist in seasonal allergic rhinitis: a parallel group controlled phase IIa study. Inflamm Res. (2015) 64:90315. doi: 10.1007/s00011-015-0873-2

194. Senti G, Freiburghaus AU, Larenas-Linnemann D, Hoffmann HJ, Patterson AM, Klimek L, et al. Intralymphatic immunotherapy: update and unmet needs. Int Arch Allergy Immunol. (2019) 178:141-9. doi: 10.1159/000493647

195. Plantinga M, Guilliams M, Vanheerswynghels M, Deswarte K, BrancoMadeira F, Toussaint W, et al. Conventional and monocyte-derived $\mathrm{CD} 11 \mathrm{~b}(+)$ dendritic cells initiate and maintain T helper 2 cell-mediated immunity to house dust mite allergen. Immunity. (2013) 38:32235. doi: 10.1016/j.immuni.2012.10.016

196. Coquet JM, Schuijs MJ, Smyth MJ, Deswarte K, Beyaert R, Braun H, et al. Interleukin-21-producing CD4(+) T cells promote type 2 immunity to house dust mites. Immunity. (2015) 43:318-30. doi: 10.1016/j.immuni.2015.07.015

197. Johnston RJ, Poholek AC, DiToro D, Yusuf I, Eto D, Barnett B, et al. Bcl6 and Blimp-1 are reciprocal and antagonistic regulators of $\mathrm{T}$ follicular helper cell differentiation. Science. (2009) 325:1006-10. doi: 10.1126/science.1175870

198. Nurieva RI, Chung Y, Martinez GJ, Yang XO, Tanaka S, Matskevitch TD, et al. Bcl6 mediates the development of T follicular helper cells. Science. (2009) 325:1001-5. doi: 10.1126/science.1176676

199. Yu D, Rao S, Tsai LM, Lee SK, He Y, Sutcliffe EL, et al. The transcriptional repressor Bcl-6 directs $\mathrm{T}$ follicular helper cell lineage commitment. Immunity. (2009) 31:457-68. doi: 10.1016/j.immuni.2009.07.002

200. Yusuf I, Kageyama R, Monticelli L, Johnston RJ, Ditoro D, Hansen K, et al. Germinal center T follicular helper cell IL-4 production is dependent on signaling lymphocytic activation molecule receptor (CD150). J Immunol. (2010) 185:190-202. doi: 10.4049/jimmunol.0903505

201. Weinstein JS, Laidlaw BJ, Lu Y, Wang JK, Schulz VP, Li N, et al. STAT4 and T-bet control follicular helper T cell development in viral infections. J Exp Med. (2018) 215:337-55. doi: 10.1084/jem.20170457

202. Luthje K, Kallies A, Shimohakamada Y, Belz GT, Light A, Tarlinton DM, et al. The development and fate of follicular helper T cells defined by an IL-21 reporter mouse. Nat Immunol. (2012) 13:491-8. doi: 10.1038/ni.2261

203. Wojciechowski W, Harris DP, Sprague F, Mousseau B, Makris M, Kusser $\mathrm{K}$, et al. Cytokine-producing effector $\mathrm{B}$ cells regulate type 2 immunity to H. polygyrus. Immunity. (2009) 30:421-33. doi: 10.1016/j.immuni.2009. 01.006

204. Hsu HC, Yang P, Wang J, Wu Q, Myers R, Chen J, et al. Interleukin 17producing $\mathrm{T}$ helper cells and interleukin 17 orchestrate autoreactive germinal center development in autoimmune BXD2 mice. Nat Immunol. (2008) 9:166-75. doi: 10.1038/ni1552

205. Leon B, Ballesteros-Tato A, Browning JL, Dunn R, Randall TD, Lund FE. Regulation of $\mathrm{T}(\mathrm{H}) 2$ development by CXCR5+ dendritic cells and lymphotoxin-expressing B cells. Nat Immunol. (2012) 13:68190. doi: $10.1038 /$ ni.2309
206. Glatman Zaretsky A, Taylor JJ, King IL, Marshall FA, Mohrs M, Pearce EJ $\mathrm{T}$ follicular helper cells differentiate from Th2 cells in response to helminth antigens. J Exp Med. (2009) 206:991-9. doi: 10.1084/jem.20090303

207. Weinstein JS, Herman EI, Lainez B, Licona-Limon P, Esplugues E, Flavell $\mathrm{R}$, et al. TFH cells progressively differentiate to regulate the germinal center response. Nat Immunol. (2016) 17:1197-205. doi: 10.1038/ni.3554

208. Reinhardt RL, Liang HE, Locksley RM. Cytokinesecreting follicular $\mathrm{T}$ cells shape the antibody repertoire. Nat Immunol. (2009) 10:385-93. doi: 10.1038/ni. 1715

209. Johnston RJ, Choi YS, Diamond JA, Yang JA, Crotty S. STAT5 is a potent negative regulator of TFH cell differentiation. J Experi Med. (2012) 209:24350. doi: 10.1084/jem.20111174

210. Nurieva RI, Podd A, Chen Y, Alekseev AM, Yu M, Qi X, et al. STAT5 protein negatively regulates $\mathrm{T}$ follicular helper (Tfh) cell generation and function. $J$ Biol Chem. (2012) 287:11234-9. doi: 10.1074/jbc.M111.324046

211. Leon B, Bradley JE, Lund FE, Randall TD, Ballesteros-Tato A. FoxP3+ regulatory $\mathrm{T}$ cells promote influenza-specific Tfh responses by controlling IL-2 availability. Nat Commun. (2014) 5:3495. doi: 10.1038/ncomms4495

212. Ballesteros-Tato, Leon B, Graf BA, Moquin A, Adams PS, Lund $\mathrm{FE}$, et al. Interleukin-2 inhibits germinal center formation by limiting $\mathrm{T}$ follicular helper cell differentiation. Immunity. (2012) 36:847-56. doi: 10.1016/j.immuni.2012.02.012

213. Botta D, Fuller MJ, Marquez-Lago TT, Bachus H, Bradley JE, Weinmann AS, et al. Dynamic regulation of $\mathrm{T}$ follicular regulatory cell responses by interleukin 2 during influenza infection. Nat Immunol. (2017) 18:124960. doi: 10.1038/ni.3837

214. Papillion, Powell MD, Chisolm DA, Bachus H, Fuller MJ, Weinmann AS, et al. Inhibition of IL-2 responsiveness by IL-6 is required for the generation of GC-TFH cells. Sci Immunol. (2019) 4. doi: 10.1126/sciimmunol.aaw7636

215. Locci M, Wu JE, Arumemi F, Mikulski Z, Dahlberg C, Miller AT, et al. Activin A programs the differentiation of human TFH cells. Nat Immunol. (2016) 17:976-84. doi: 10.1038/ni.3494

216. Oestreich KJ, Read KA, Gilbertson SE, Hough KP, McDonald PW, Krishnamoorthy V, et al. Bcl-6 directly represses the gene program of the glycolysis pathway. Nat Immunol. (2014) 15:957-64. doi: 10.1038/ni.2985

217. He, Zhang X, Wei Y, Sun X, Chen Y, Deng J, et al. Low-dose interleukin-2 treatment selectively modulates CD4(+) $\mathrm{T}$ cell subsets in patients with systemic lupus erythematosus. Nat Med. (2016) 22:991-3. doi: $10.1038 / \mathrm{nm} .4148$

218. Ballesteros-Tato, Papillion A. Mechanisms of action of low-dose IL2 restoration therapies in SLE. Curr Opin Immunol. (2019) 61:3945. doi: 10.1016/j.coi.2019.07.003

219. Saadoun D, Rosenzwajg M, Joly F, Six A, Carrat F, Thibault V, et al. Regulatory T-cell responses to low-dose interleukin-2 in HCV-induced vasculitis. N Engl J Med. (2011) 365:2067-77. doi: 10.1056/NEJMoal 105143

220. Koreth J, Matsuoka K, Kim HT, McDonough SM, Bindra B, Alyea $\mathrm{EP}$, et al. Interleukin-2 and regulatory $\mathrm{T}$ cells in graft-versus-host disease. N Engl J Med. (2011) 365:2055-66. doi: 10.1056/NEJMoal1 08188

Conflict of Interest: The authors declare that the research was conducted in the absence of any commercial or financial relationships that could be construed as a potential conflict of interest.

Copyright (c) 2021 León and Ballesteros-Tato. This is an open-access article distributed under the terms of the Creative Commons Attribution License (CC BY). The use, distribution or reproduction in other forums is permitted, provided the original author(s) and the copyright owner(s) are credited and that the original publication in this journal is cited, in accordance with accepted academic practice. No use, distribution or reproduction is permitted which does not comply with these terms. 